This report was prepared as an account of work sponsored by an agency of the United States Government. Neither the United States Government nor any agency thereof, nor any of their employees, makes any warranty, express or implied, or assumes any legal liability or responsibility for the accuracy, completeness, or usefulness of any information, apparatus, product, or process disclosed, or represents that its use would not infringe privately owned rights. Reference herein to any specific commercial product, process, or service by trade name, trademark, manufacturer, or otherwise does not necessarily constitute or imply its endorsement, recommendation, or favoring by the United States Government or any agency thereof. The views and opinions of authors expressed herein do not necessarily state or reflect those of the United States Government or any agency thereof.

\author{
Energy Division
}

\title{
EVALUATION OF NEPA-BASED ENVIRONMENTAL COMMITTMENTS AT FOUR GEOPRESSURE DESIGN WELLS
}

\begin{abstract}
A. W. Reed
D. B. Hunsaker, Jr.
\end{abstract}

R. D. Roop

J. W. Webb*

Environmental Sciences Division, ORNL.

Date of Issue-September 1983

Prepared by the

OAK RIDGE NATIONAL LABORATORY

Oak Ridge, Tennessee 37830 operated by UNION CARBIDE CORPORATION for the U.S. DEPARTMENT OF ENERGY under Contract No. W-7405-eng-26 


\section{DISCLAIMER}

This report was prepared as an account of work sponsored by an agency of the United States Government. Neither the United States Government nor any agency Thereof, nor any of their employees, makes any warranty, express or implied, or assumes any legal liability or responsibility for the accuracy, completeness, or usefulness of any information, apparatus, product, or process disclosed, or represents that its use would not infringe privately owned rights. Reference herein to any specific commercial product, process, or service by trade name, trademark, manufacturer, or otherwise does not necessarily constitute or imply its endorsement, recommendation, or favoring by the United States Government or any agency thereof. The views and opinions of authors expressed herein do not necessarily state or reflect those of the United States Government or any agency thereof. 


\section{DISCLAIMER}

Portions of this document may be illegible in electronic image products. Images are produced from the best available original document. 
Sow 


\section{CONTENTS}

Page

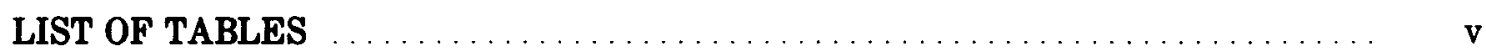

LIST OF FIGURES $\ldots \ldots \ldots \ldots \ldots \ldots \ldots \ldots \ldots \ldots \ldots \ldots \ldots \ldots \ldots \ldots \ldots \ldots \ldots$

ACRONYMS AND INITIALISMS $\ldots \ldots \ldots \ldots \ldots \ldots \ldots \ldots \ldots \ldots \ldots \ldots \ldots \ldots \ldots \ldots$

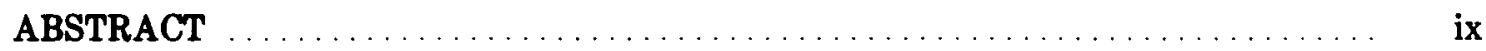

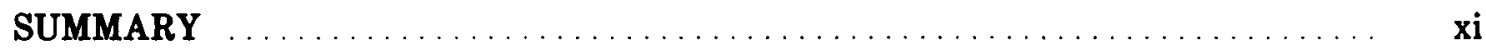

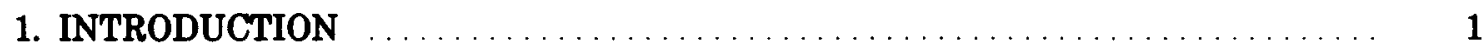

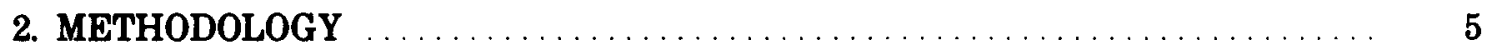

3. EVALUATION OF COMMITMENTS $\ldots \ldots \ldots \ldots \ldots \ldots \ldots \ldots \ldots \ldots \ldots$

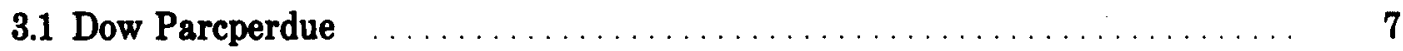

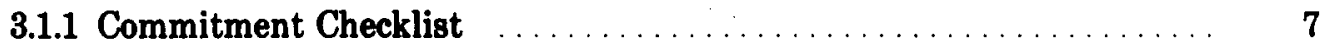

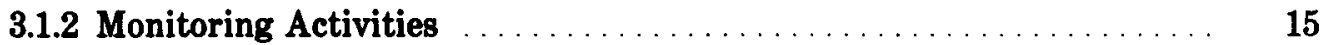

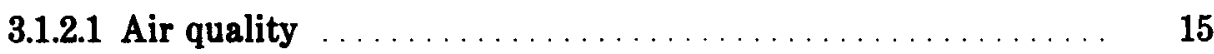

3.1.2.2 Noise . . . . . . . . . . . . . . . . . . . . . . . . . . . 18

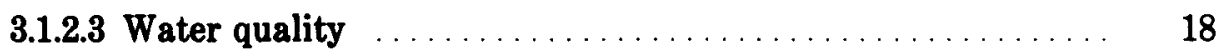

3.1.2.4 Ecology . . . . . . . . . . . . . . . . . . . . . . . . . 18

3.1.2.5 Subsidence and microseismicity $\ldots \ldots \ldots \ldots \ldots \ldots \ldots \ldots, 19$

3.1.3 Decommissioning . . . . . . . . . . . . . . . . . . . . . 19

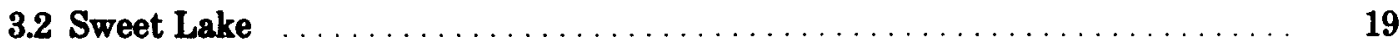

3.2.1 Commitment Checklist $\ldots \ldots \ldots \ldots \ldots \ldots \ldots \ldots \ldots \ldots \ldots \ldots \ldots$

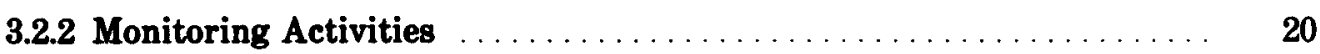

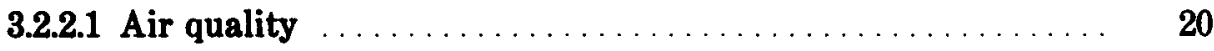

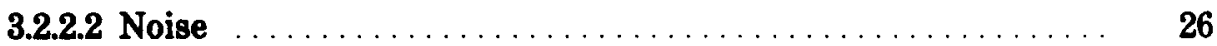

3.2.2.3 Water quality $\ldots \ldots \ldots \ldots \ldots \ldots \ldots \ldots \ldots \ldots \ldots, \quad 27$

3.2.2.4 Ecology $\ldots \ldots \ldots \ldots \ldots \ldots \ldots \ldots \ldots \ldots \ldots \ldots \ldots \ldots, \quad 27$

3.2.2.5 Subsidence and microseismicity $\ldots \ldots \ldots \ldots \ldots \ldots \ldots \ldots 28$

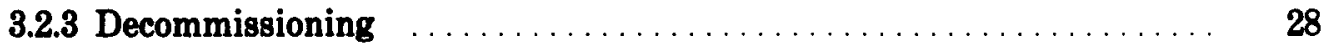




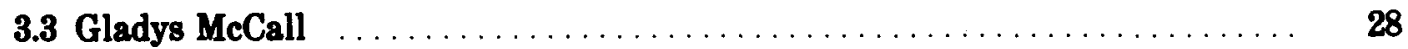

3.3.1 Commitment Checklist $\ldots \ldots \ldots \ldots \ldots \ldots \ldots \ldots \ldots \ldots \ldots \ldots 29$

3.3.2 Monitoring Activities $\ldots \ldots \ldots \ldots \ldots \ldots \ldots \ldots \ldots \ldots \ldots \ldots, 35$

3.3.2.1 Air quality $\ldots \ldots \ldots \ldots \ldots \ldots \ldots \ldots \ldots \ldots \ldots \ldots \ldots \ldots \ldots \ldots, 35$

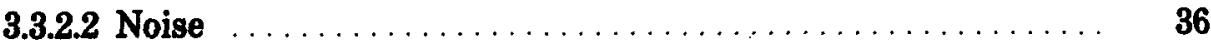

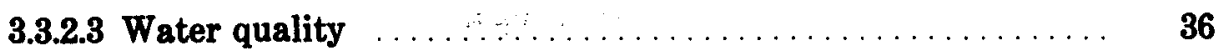

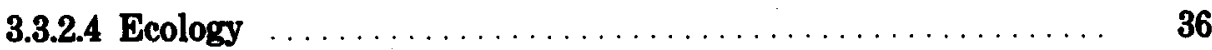

3.3.2.5 Subsidence and microseismicity $\ldots \ldots \ldots \ldots \ldots \ldots \ldots \ldots, \quad 38$

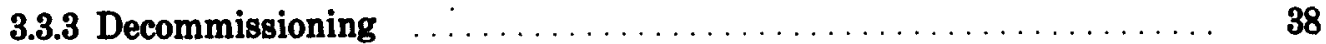

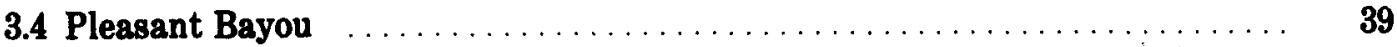

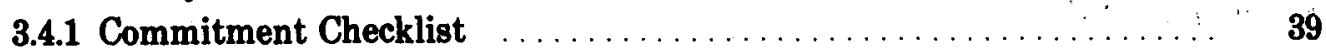

3.4.2 Monitoring Activities $\ldots \ldots \ldots \ldots \ldots \ldots \ldots \ldots \ldots \ldots, 42$

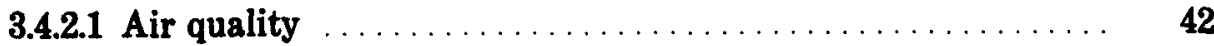

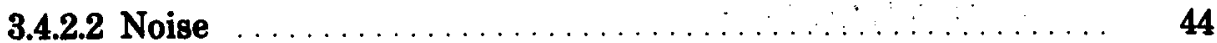

3.4.2.3 Water quality $\ldots \ldots \ldots \ldots \ldots \ldots \ldots \ldots \ldots \ldots \ldots \ldots, 45$

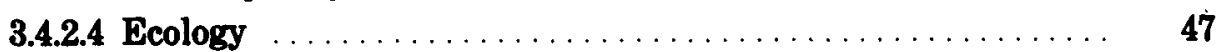

3.4.2.5 Subsidence and microseismicity $\ldots \ldots \ldots \ldots \ldots \ldots \ldots \ldots, 47$

3.4.3 Decommissioning $\ldots \ldots \ldots \ldots \ldots \ldots \ldots \ldots \ldots \ldots \ldots \ldots, 49$

4. CONCLUSIONS AND RECOMMENDATIONS $\ldots \ldots \ldots \ldots \ldots \ldots \ldots \ldots \ldots$

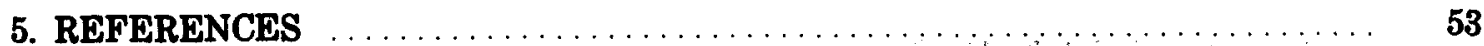

APPENDIX A-SUMMARY OF RESEARCH CONCERNING
THE EFFECTS OF DRILIING MUD PITS
ON GROUNDWATER QUALITY $\ldots \ldots \ldots \ldots \ldots \ldots \ldots \ldots \ldots \ldots$




\section{LIST OF TABLES}

Table

1 Mitigation and monitoring checklist for the Dow Parcperdue geopressure design well, Vermilion Parish, Louisiana

2 Mitigation and monitoring commitment checklist for the Sweet Lake No. 1 geopressure design well, Cameron Parish, Louisiana

3 Mitigation and monitoring commitment checklist for the Gladys McCall geopressure design well, Cameron Parish, Louisiana

4 Mitigation and monitoring commitment checklist for the Pleasant Bayou geopressure design well, Brazoria County, Texas

A.1 Characteristics of drilling mud pits $\ldots \ldots \ldots \ldots \ldots \ldots \ldots \ldots \ldots \ldots \ldots$

A.2 Mean concentration of parameters in groundwater samples at drilling mud pit sites evaluated

A.3 Frequency of exceedance of primary and secondary drinking water standards for selected parameters measured in groundwater samples at drilling mud pit sites evaluated

A.4 Magnitude of exceedance of primary and secondary drinking water standards for selected parameters measured in groundwater samples at drilling mud pit sites evaluated 


\section{LIST OF FIGURES}

1 Locations of the four geopressure design wells evaluated in this study

2 Locations of field environmental monitoring stations near the Dow Parcperdue geopressure design well

3 Locations of field environmental monitoring stations near the Sweet Lake No. 1 geopressure design well

4 Locations of field environmental monitoring stations near the Gladys McCall geopressure design well

5 Location of air quality monitoring station near the Pleasant Bayou geopressure design well

6 Predicted sound levels from well drilling near the

Pleasant Bayou geopregsure design well

7 Locations of groundwater monitoring stations near the Pleasant Bayou geopressure design well 


\section{ACRONYMS AND INITIALISMS}

DOE U.S. Department of Energy

EA Environmental Assessment

EIS Environmental Impact Statement

EPA U.S. Environmental Protection Agency

ERDA U.S. Energy Research and Development Administration

FONSI Finding of No Significant Impact

FY Fiscal year

LSU Louisiana State University

NAAQS National Ambient Air Quality Standards

NEPA National Environmental Policy Act

NMHC Nonmethane hydrocarbons

ORNL Oak Ridge National Laboratory

P\&A Plugging and abandonment

THC Total hydrocarbons

TNMHC Total nonmethane hydrocarbons

TSP Total suspended particulates

UIC Underground Injection Control 


\begin{abstract}
The implementation of environmental mitigation and monitoring commitments made by the U.S. Department of Energy (DOE) in documents prepared (pursuant to the National Environmental Policy Act) for four geopressure design well projects was evaluated by Oak Ridge National Laboratory (ORNL) staff. The evaluation was based on site visits conducted in August 1982 and April 1983 and on a review of monitoring and project activity reports provided by DOE contractors. The projects evaluated include: Pleasant Bayou No. 1 in Brazoria County, Texas; Dow Parcperdue in Vermilion Parish, Louisiana; and Gladys McCall and Sweet Lake No. 1 well sites in Cameron Parish, Louisiana.

The contractors responsible for drilling and testing activities at the well sites have adequately implemented most of the mitigation measures described in each project's sitespecific Environmental Assessment (EA). Exceptions include the lack of impermeable liners for drilling mud pits at the Dow Parcperdue, Gladys McCall, and Pleasant Bayou sites and the lack of a ring levee at the Pleasant Bayou site. Air and water quality and noise monitoring activities were not performed as strictly as outlined in the EAs.

A review of the monitoring data collected to date indicates that no significant environmental degradation has occurred. This report recommends additional or future monitoring needs, especially with regard to soil contamination, subsidence, and microseismicity, and provides guidance for decommisioning.
\end{abstract}




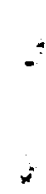

$\therefore$
$\because \cdots$

$\checkmark$

$\bullet$ 


\section{SUMMARY}

This report verifies the implementation of environmental mitigation and monitoring commitments made by the U.S. Department of Energy (DOE) in National Environmental Policy Act (NEPA) documents [Environmental Assessments (EAs)] prepared for four geopressure design well projects, one in Texas (Pleasant Bayou) and three in Louisiana (Dow Parcperdue, Gladys McCall, and Sweet Lake). The evaluation is based on visits to the project sites conducted by Oak Ridge National Laboratory (ORNL) staff in August 1982 and April 1983 and on a review of monitoring and project activity reports provided by DOE contractors.

Contractors responsible for drilling and testing activities at the well sites have adequately implemented most of the mitigation measures described in each project's EA. Exceptions include the lack of impermeable liners for drilling mud pits at the Dow, Gladys McCall, and Pleasant Bayou sites and the lack of a ring levee at the Pleasant Bayou site.

Water quality, noise, and air monitoring were not performed as strictly as outlined in the EAs. The reasons are twofold: (1) the initial testing at the Pleasant Bayou and Sweet Lake sites indicated little change in baseline concentrations or ambient levels of those parameters being monitored and (2) federal funding cutbacks have resulted in the termination of some monitoring and the failure to initiate that which had been planned. A review of the data collected to date indicates that no significant environmental degradation has occurred. The ORNL staff has recommended additional or future monitoring needs, especially with regard to subsidence, microseismicity, and groundwater and soil sampling. In addition, one or more future follow-up site visits is planned.

Because of the effectiveness of mitigation and monitoring for these geopressure projects and because of the generally benign nature of geothermal energy resource development and utilization, the environmental impacts of the DOE design well program have been few and minor. Follow-up activities such as those undertaken in this study would be useful for all extant federal projects that have undergone the NEPA environmental review process, particularly those involving more significant impacts than those of geothermal projects.

Firm decisions with regard to the future of the geopressure design well program have not been made. It is recommended that, when the projects are decommissioned, DOE ensure that abandonment of the wells meets all federal, state, and local requirements and that the sites are restored either to their original conditions or to the extent specified in the EAs. 


\section{INTRODUCTION}

In 1976, the U.S. Energy Research and Development Administration [ERDA; now the Department of Energy (DOE)], Division of Geothermal Energy, established a Geopressure Subprogram intended to encourage the development of a viable industry to exploit the geothermal geopressured resource along the Texas-Louisiana Gulf Coast. To stimulate industrial interest in development of the unproven geopressured resource, ERDA initiated exploration of the range of technical, economic, and institutional factors associated with development of this resource. Subprogram activities were categorized into resource development, resource utilization, engineering research and development, and environmental control and institutional studies. Resource development support has been focused on exploration technology, resource assessment, and reservoir confirmation. Resource assessment has involved well production tests and the acquisition of specific geopressured reservoir information on a regional basis. Both these latter tasks have been accomplished, in part, by the drilling and testing of four geopressure design wells.

The drilling and testing undertaken at the four DOE geopressure wells generally involve the following activities. First, wells are drilled. A production well is drilled into the geopressured geothermal zone [3000-4000 m (10,000-15,000 ft)]; an injection (disposal) well is drilled to about one-third the depth of the production well. (Disposal wells for geopressure projects differ from those used in hydrothermal projects, which typically reinject to the production zone, primarily to avoid the higher costs and technical problems that accompany drilling into geopressured zones.) Well drilling is followed by production, testing, and reinjection.

Production of geothermal brine from the reservoir yields a high-temperature $\left[121-148^{\circ} \mathrm{C}\right.$ $\left.\left(250-300^{\circ} \mathrm{F}\right)\right]$, pressurized fluid consisting of steam, noncondensable gases, and water. When it reaches the surface, the fluid passes through a gas separator to remove methane and other noncondensable gases. The gas is then flared. If it is to be sold, the gas may be treated to remove hydrogen sulfide, carbon dioxide, and/or water vapor prior to sale. The produced fluid that remains after removal of gas is then used to determine the volume of the reservoir (cumulative data), physical and chemical characteristics of the brine, and production capability of the reservoir (e.g., from flow rates and other physical measurements). After testing, the brine is reinjected via the disposal well.

Testing of geopressured systems is intended to generate data that may be used to develop potential future applications, including (1) generation of electricity by use of the thermal energy of the fluid, (2) direct use of the thermal energy for process or residential heating systems, (3) harnessing of hydraulic energy for industrial use, and (4) the production of natural gas for residential/commercial consumption.

This report evaluates the environmental mitigation and monitoring commitments made by DOE with regard to activities of the geopressure design well program of the Geopressure 
Subprogram, Geothermal and Hydropower Technologies Division. The purpose of this study was to verify implementation of measures outlined in environmental documents prepared for four geopressure design well projects pursuant to the National Environmental Policy Act (NEPA) of 1969. NEPA analyses are performed and published to satisfy legal requirements prior to the initiation of a proposed federal action. These analyses play a major role in the decision making that affects the future of many projects; however, more often than not, little or no follow-up analyses are carried out to assure decision makers that environmental protection requirements are actually implemented or that they are effective. Although NEPA requires follow-up only for environmental impact statements (EISs), this study provides a necessary follow-up to environmental assessments (EAs) of the design well projects. Environmental monitoring and the design and implementation of mitigation measures are related components of the NEPA process. Typically, mitigation measures are designed to ameliorate any predicted or potential impacts. Monitoring is initially conducted to characterize the environmental baseline and later to provide early warning of unanticipated impacts or of the need for additional or improved mitigation measures.

The study was conducted by Oak Ridge National Laboratory (ORNL) staff members, some of whom were involved in the preparation of the programmatic and site-specific geopressure design well EAs. The projects evaluated include Pleasant Bayou No. 1 in Brazoria County, Texas; Dow Parcperdue in Vermilion Parish, Louisiana; and Gladys McCall and Sweet Lake No. 1 well sites in Cameron Parish, Louisiana (see Fig. 1). Section 2 of this report presents the methodology used for evaluating mitigation and monitoring commitments at these sites, Sect. 3 presents the results of the evaluation, and Sect. 4 provides conclusions and recommendations. 


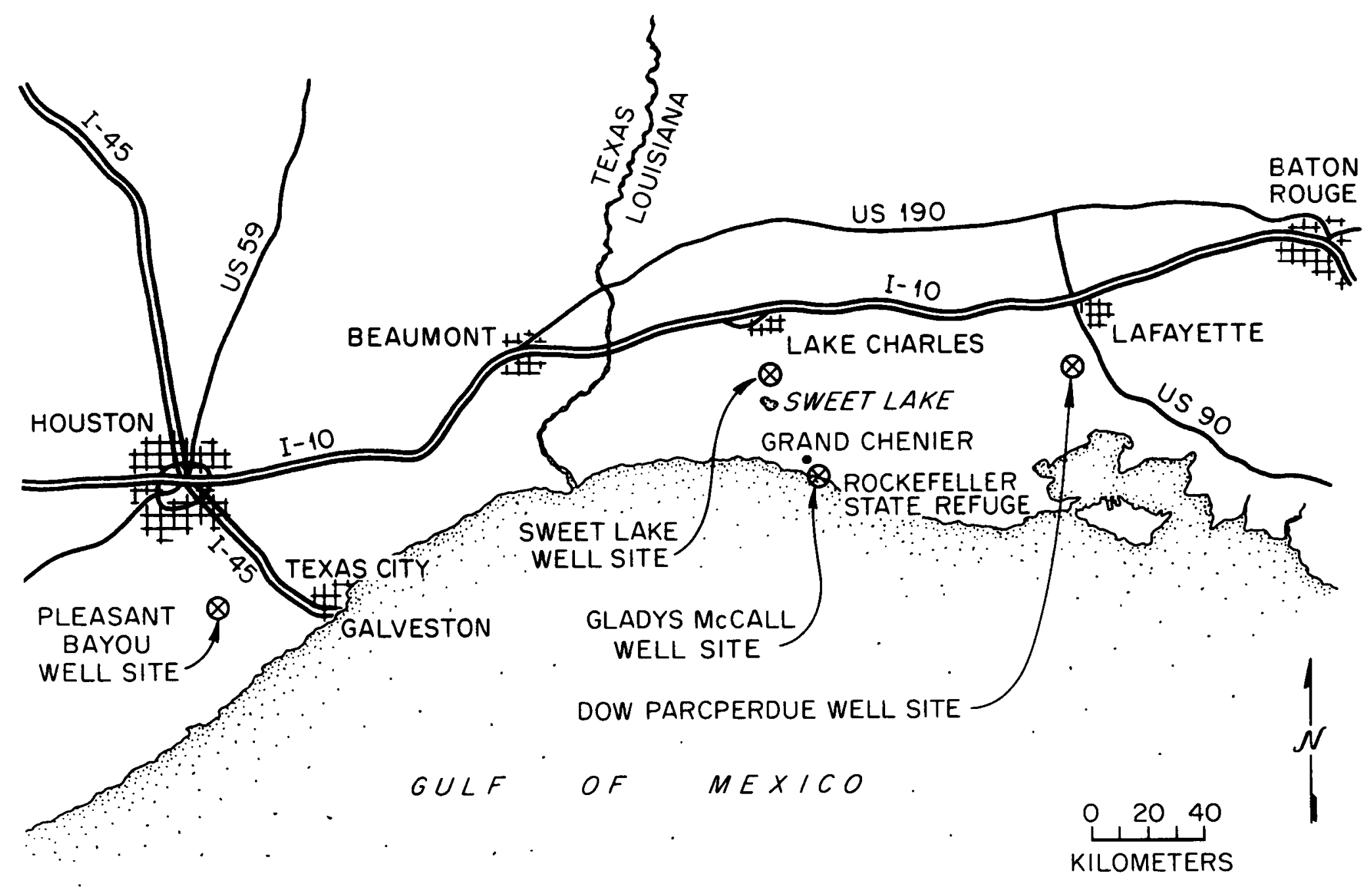

Fig. 1. Locations of the four geopressure design wells evaluated in this study. 
:

. 


\section{METHODOLOGY}

To provide a basis for evaluation of the environmental mitigation and monitoring commitments made by DOE at four geopressure design well projects, the ORNL staff reviewed site-specific EAs prepared for each project, "Findings of No Significant Impact" (FONSIs), and/or memoranda, if available and pertinent. The documents reviewed include:

- Dow Parcperdue: Draft Environmental Assessment, Dow Parcperdue Geopressure Project, Vermilion Parish, Louisiana, March 1980 (DOE,1980a); memorandum dated May 9, 1980 (Clusen, 1980a).

- Sweet Lake: Environmental Assessment, Geothermal Energy Geopressure Subprogram, DOE Sweet Lake No. 1, Cameron Parish, Louisiana, DOE/EA-0065, February 1980 (DOE, 1980b); FONSI dated March 11, 1980 (Clusen, 1980b).

- Gladys McCall: Envirommental Assessment, Geothermal Energy Geopressure Subprogram, DOE Gladys McCall Well Site, Cameron Parish, Louisiana, DOE/EA-0134, January 1981 (DOE, 1981); FONSI dated March 16, 1981.

- Pleasant Bayou: Environmental Assessment, Geothermal Energy Geopressure Subprogram, GCO-DOE, Pleasant Bayou No. 1, Brazoria County, Texas, DOE/EA-0013, March 1978 (DOE, 1978); memoranda dated March 27, 1978 (Liverman, 1978) and January 15, 1979 (Cotter, 1979).

Following a review of the preceding documents, a detailed checklist was prepared, identifying commitments made by DOE with regard to mitigation of potential environmental impacts, baseline and operational monitoring, and future decommissioning of each project. Each checklist included a general classification of the resource area affected (e.g., land resources), a reference to the document and page on which the commitment was made, a verbatim excerpt of each commitment, and an identification of the project phase in which the commitment was to be fulfilled.

When the checklists were complete, the ORNL staff contacted DOE monitoring contractors in Texas and Louisiana to obtain progress and/or annual reports with regard to current and past monitoring activities. Environmental monitoring in Louisiana was conducted by the Louisiana Geological Survey, and monitoring activities in Texas were performed at the direction of the University of Texas, Bureau of Economic Geology. All available reports were reviewed, and monitoring activities were compared with the commitments outlined in EAs, FONSIs, and other documents. Specific data and information were obtained through personal communications with the individual contractors.

Site operating contractors were contacted next. The site managers provided ORNL with progress reports and described the current status of each project. Arrangements were made for the ORNL project staff to visit each site to (1) verify the implementation of 
commitments made in the NEPA documents, using the checklists as a guide, and (2) determine future mitigation and monitoring needs related to restoration of the site upon decommissioning of the design wells.

Site visits were conducted as follows: August 10, 1982, and April 24, 1983, Dow Parcperdue; August 11, 1982, Sweet Lake; August 12, 1982, and April 25, 1983, Gladys McCall; and August 13, 1982, Pleasant Bayou: Verification of commitments involved direct physical inspection of facilities and discussions with the site manager or project manager. In addition, personnel from the Louisiana Geological Survey accompanied the ORNL team on the initial Dow site visit to serve as first-hand witnesses to monitoring activities at that location.

Subsequent to the site visits, ORNL staff prepared reports for each geopressure design well project. The reports which follow provide a brief background description of the project and its current status; a verification of commitments outlined in NEPA documents; a description of any revisions to original commitments which have been implemented; a description of future mitigation and monitoring plans; recommendations for future mitigation and monitoring; and a brief description of future plans for each project, based on discussions with the Geopressure Program Manager in. Washington, D.C., and with the site managers. 


\section{EVALUATION OF COMMITMENTS}

\subsection{Dow Parcperdue}

At the Dow site, a well was drilled into the geopressured reservoir to produce from the reservoir until the resource was depleted. Dow obtained from the owner, Lee Roy Sweezy, a geothermal lease of a 15.2-ha (37.5-acre) tract of land, now known as the Sweezy tract.

From site preparation to site restoration, the project was originally scheduled to last 24 months. Throughout this period the surrounding environment was to be monitored as described in the Environmental Monitoring Plan in Appendix A of the EA (DOE, 1980a). Site preparation began in January 1981. The production well was completed in the summer of 1981 at a depth of about $4,069 \mathrm{~m}(13,350 \mathrm{ft})$, and preliminary flow testing began in October 1981. The injection well was drilled in early 1982 at a depth of about $1,524 \mathrm{~m}(5,000$ ft) (C. K. Geoenergy, 1982a). The Dow well typically produced about $1,590 \mathrm{~m}^{3}(10,000 \mathrm{bbl})$ of brine per day and about $4250 \mathrm{~m}^{8}\left(150,000 \mathrm{ft}^{3}\right)$ of gas per day. Increasing the brine production rate above this value produced severe sanding problems that restricted production to about half the design value (Dow, 1982). The experiment was designed for a brine flow production of about $3,180 \mathrm{~m}^{3} / \mathrm{d}(20,000 \mathrm{bbl} / \mathrm{d})$.

Well testing was to have continued through June 1983 and the project decommissioned during July and August 1983. However, on February 5, 1983, the well was shut-in to determine why the gas flare was not burning although brine production was contining. Upon inspection, it was found that the gas separator and sand filters contained approximately 4 to $5 \mathrm{bbl}$ of fine sand and clay. On February 8, 1983, about $150 \mathrm{~m} \mathrm{(500} \mathrm{ft)} \mathrm{of} \mathrm{sand} \mathrm{was}$ detected above the perforations in the producing well. The disposal well was filled with sand to about $6 \mathrm{~m}(20 \mathrm{ft})$ above the perforations. DOE decided to terminate the Dow project at that time. The cost of restoring the wells and the above-ground equipment to original operating condition, combined with the limited amound of data yet to be obtained, were major factors contributing to the decision to abandon the wells ahead of schedule. On March 30 the plugging and abandonment (P\&A) procedure was completed for the disposal well, and on April 7 the P\&A was completed for the production well. All procedures were in accordance with Louisiana Office of Conservation regulations for the drilling, production, and plugging of geothermal wells (Rule XVI of Statewide Order No. 29-P). Project decommissioning and site restoration were completed in May 1983.

\subsubsection{Commitment Checklist}

This section verifies monitoring and mitigation commitments in the EA for the Dow geopressure design well. The bases for this verification were onsite inspections using a 
checklist consisting of a summary of all statements concerning monitoring and mitigation that were made in the NEPA documents prepared for the project.

Table 1 presents the checklist for the Dow well, as verified on August 10, 1982. Further comments are included in the text, based on a follow-up site visit in April 1983. The following items are noted:

- Use of pit liners-The drilling mud pit was approximately 61 by $102 \mathrm{~m}$ (200 by $335 \mathrm{ft}$ ) in size. The liner (8-mm black polyethylene) was torn for approximately 12 months, after which it was repaired. During this period, toxic materials in the mud, if any, had a pathway by which to contaminate the soil and groundwater. [It must be noted that the liner was approximately $8 \mathrm{~mm}$ ( $0.3 \mathrm{in}$.) of black polyethylene plastic, a material more likely to tear than commercial-grade pit liners.) An additional pit was constructed at the well site as a temporary brine-holding pit [size approximately 31 by $61 \mathrm{~m}$ (100 by $200 \mathrm{ft}$ )]. This was also lined, and during the August site visit, the liner appeared to be intact. However, during the completion of a build-up test on November 5 , 1982, a drop in the level of brine in the brine pit was detected. Because no brine had been pumped, a leak was suspected. Inspection determined that brine had entered an adjacent drainage ditch. The brine pit was emptied by injection into the disposal well Subsequent inspection of the liner identified two $33-\mathrm{m}(110-\mathrm{ft})$ and two $20-\mathrm{m}$ (65-ft) rips; the liner had apparently separated along field-applied seams because of the upward pressure of gas bubbles (most likely methane from decomposition of organic matter): Louisiana State University (LSU) began monitoring salinity and conductivity at several surface sites established, because of the leak and continued monitoring salinity-related parameters (i.e., chloride) at previously established surface water and groundwater monitoring stations. Data collected on November 15,1982 ; indicated that conductivity and salinity were above background levels. Levels of water quality parameters associated with salinity were observed to decrease with time; chloride concentration at the LeBlanc Ditch Station [approximately $5 \mathrm{~km}(3 \mathrm{mi})$ southwest of the well site] was about $273 \mathrm{ppm}$ in November and about $10.5 \mathrm{ppm}$ in February (Trahan, 1983). When compared to mean concentrations of chloride in the geothermal brine $(55,000 \mathrm{ppm}$; Keeley and Meriwether, 1983), contamination was relatively low. The environmental impacts of the torn liner appear to have been minimized by the quick action of the onsite crew in removing the water from the ditch and in flushing the ditch with fresh water. As part of the decommissioning of the Dow well, soil samples in the pit and around its north leveee were analyzed by Southern Petroleum Laboratory in April 1983. Gulf Coast Agricultural Associates Inc., an agricultural consulting firm that assisted Dow in project decommissioning, reviewed the soil analysis data and recommended that the entire north levee and no less than $0.3 \mathrm{~m}(1 \mathrm{ft})$ of soil on the bottom of the pit be removed for appropriate offsite disposal.

- Hydrogen sulfide $\left(\mathrm{H}_{2} \mathrm{~S}\right)$ removal-Because no measurable quantities of $\mathrm{H}_{2} \mathrm{~S}$ were found in the natural gas extracted from the well (Keeley and Meriwether, 1982), the $\mathrm{H}_{2} \mathrm{~S}$ removal equipment planned as a mitigation measure was not needed. The gas was flared, and any trace amounts of $\mathrm{H}_{2} \mathrm{~S}$ present were most likely oxidized to sulfur dioxide $\left(\mathrm{SO}_{2}\right)$. 
Table 1. Mitigation and monitoring chocklist for the Dow Parcperdue geopresenre deaign well, Vermilion Parish, Louisiana

\begin{tabular}{|c|c|c|c|c|c|}
\hline & Page no. in EA ${ }^{a}$ & Commitment $^{b}$ & Project phase $^{c}$ & Verification $^{d}$ & Recommendations \\
\hline \multirow[t]{3}{*}{$\begin{array}{l}\text { General site } \\
\text { preparation }\end{array}$} & $2-1,2-3,2-5$ & $\begin{array}{l}\text { "Dow proposes to relocate a } \\
\text { shallow drainage ditch } \\
\text { which crosses the } \\
\text { project site." }\end{array}$ & C & $\mathbf{F}$ & None \\
\hline & $2-3$ & $\begin{array}{l}\text { "Materials excavated during } \\
\text { the (mud) pit's con- } \\
\text { struction will be placed } \\
\text { along its sides to form } \\
\text { a dike. . it will be } \\
\text { lined with an impervious } \\
\text { material." }\end{array}$ & C & $\mathbf{F}$ & None \\
\hline & $2-3$ & $\begin{array}{l}\text { "A ring levee ( }(3 \mathrm{ft}) \text { will } \\
\text { surround project... } \\
\text { land around it will } \\
\text { be sloped to provide } \\
\text { drainage." }\end{array}$ & C & $\mathbf{F}$ & None \\
\hline \multirow[t]{2}{*}{$\begin{array}{l}\text { Land resounces } \\
\text { erosion }\end{array}$} & $2-3,2-4$ & $\begin{array}{l}\text { "To prevent erosion, vege- } \\
\text { tative cover will be. } \\
\text { planted on the ring } \\
\text { levee and on the dike } \\
\text { around the mud pit." }\end{array}$ & C & $\mathbf{F}$ & None \\
\hline & $4-6$ & $\begin{array}{l}\text { "Any heavy erosion areas } \\
\text { will be graveled." }\end{array}$ & C & $\mathbf{F}$ & None \\
\hline subsidence & $4-8$ & $\begin{array}{l}\text { "A first-order leveling } \\
\text { survey will be con- } \\
\text { ducted to establish } \\
\text { baseline elevation bench- } \\
\text { marks at the site } \\
\text { prior to production." }\end{array}$ & PC & $\mathbf{F}$ & None \\
\hline seismicity & $4-8$ & $\begin{array}{l}\text { "Microseismic surveys will be } \\
\text { conducted prior to and } \\
\text { during the proposed } \\
\text { project after a recon- } \\
\text { naissance survey has been } \\
\text { conducted to determine } \\
\text { optimum locations for } \\
\text { permanent monitoring } \\
\text { stations." }\end{array}$ & PC & $\mathbf{F}$ & None \\
\hline
\end{tabular}


Table 1. (Continued)

\begin{tabular}{|c|c|c|c|c|c|}
\hline & Page no. in $\mathrm{EA}^{a}$ & Commitment $^{b}$ & Project phase $^{c}$ & Verification $^{d}$ & Recommendations \\
\hline $\begin{array}{l}\text { Water resources } \\
\text { turbidity }\end{array}$ & $4-1$ & $\begin{array}{l}\text { "The existing access road to } \\
\text { the site will be } \\
\text { upgraded. . . a ring dike will } \\
\text { confine waters to site." }\end{array}$ & $\mathbf{C}$ & $\mathbf{F}$ & None \\
\hline \multirow[t]{3}{*}{ groundwater } & $2-3$ & $\begin{array}{l}\text { ". it (the mud pit) will be } \\
\text { lined with an imper- } \\
\text { vious material." }\end{array}$ & C, 0 & $\begin{array}{l}\text { F; however, } \\
\text { liner was torn } \\
\text { for about a year }\end{array}$ & $\begin{array}{l}\text { Sampling and analysis } \\
\text { of material in } \\
\text { pit or soil under }\end{array}$ \\
\hline & & $\because \quad \therefore \ldots$ & & & $\begin{array}{l}\text { liner (fulfilled during } \\
\text { decommissioning). }\end{array}$ \\
\hline & $2-3$ & $\begin{array}{l}\text { "An adequate septic system } \\
\text { will be installed for } \\
\text { disposal of sanitary } \\
\text { wastes." }\end{array}$ & $\mathrm{C}, \mathrm{O}$ & $\mathbf{F}$ & None \\
\hline$\therefore$ & $2-7$ & "The disposal wells will & 0 & $\mathbf{F}$ & None \\
\hline$\because: \quad:$ & “ & $\begin{array}{l}\text { comply with the UIC } \\
\text { [Underground Injection Control] } \\
\text { program." }\end{array}$ & $\therefore$ & & \\
\hline $\begin{array}{l}\text { Air quality } \\
\text { gaseous emissions }\end{array}$ & 4-10 & $\begin{array}{l}\text { "Any } \mathrm{H}_{2} \mathrm{~S}_{\text {will be, removed by }} \\
\text { ion exchange and con- } \\
\text { verted to } \mathrm{SO}_{4} \cdot \\
\end{array}$ & $\mathbf{0}$ & $\begin{array}{l}\text { Not applicable; no } \\
\mathrm{H}_{2} \mathrm{~S} \text { found; all } \\
\text { gases are being } \\
\text { flared. }\end{array}$ & None \\
\hline Noise & $4-4$ & $\begin{array}{l}\text { ". proper orientation of } \\
\text { the rig will reduce } \\
\text { sound levels. . }\end{array}$ & 0 & $\boldsymbol{F}$ & None \\
\hline Wastes & $4-7$ & "All solid and liquid wastes & $\mathrm{C}, 0$ & $\mathbf{F}$ & None \\
\hline 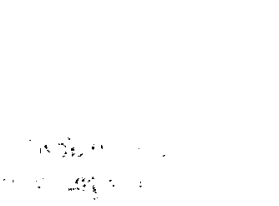 & .. & $\begin{array}{l}\text { other than spent brine } \\
\text { will be collected and } \\
\text { hauled by truck to } \\
\text { approved landfills. Human } \\
\text { wastes will be treated in } \\
\text { septic tanks." }\end{array}$ & & & \\
\hline$\cdots \cdots$ & & $\cdots$ & & . & \\
\hline$\ldots \ldots$ & w & $\begin{array}{c}: \quad \therefore \\
\therefore \quad \therefore<\cdots\end{array}$ & $\cdots \quad \cdots$ & $\therefore+\cdots: \quad \cdots$ & $\therefore$ \\
\hline
\end{tabular}


Table 1. (Continued)

\begin{tabular}{|c|c|c|c|c|c|}
\hline & Page no. in $\mathrm{EA}^{a}$ & Commitment ${ }^{b}$ & Project phase $^{c}$ & Verification ${ }^{d}$ & Recommendations \\
\hline Drilling & $2-6$ & $\begin{array}{l}\text { "Drilling wastes will be } \\
\text { temporarily stored in } \\
\text { the mud pit. . .later } \\
\text { disposed of at an } \\
\text { approved landfill." }\end{array}$ & 0 & $\begin{array}{l}\text { Some portion of } \\
\text { of the mud pit } \\
\text { contents will be } \\
\text { used as a soil } \\
\text { amendment for } \\
\text { pastureland and } \\
\text { will not be re- } \\
\text { moved for offsite } \\
\text { disposal. }\end{array}$ & None \\
\hline Accidents & $\begin{array}{c}2-10,4-11 \\
4-17\end{array}$ & $\begin{array}{l}\text { ". . the ring dike and install- } \\
\text { ation of the synthetic pad } \\
\text { liner will serve to con- } \\
\text { trol erosion and to ensure } \\
\text { effective retention of } \\
\text { any subsequent spills..." }\end{array}$ & $\mathrm{C}, 0$ & $\begin{array}{l}\text { No erosion has been } \\
\text { encountered; liner } \\
\text { in place; no major } \\
\text { spills occurred } \\
\text { during life of } \\
\text { project. }\end{array}$ & None \\
\hline spills & $2-10$ & $\begin{array}{l}\text { "Small spills or leaks can be } \\
\text { collected by a vacuum } \\
\text { truck..." }\end{array}$ & $\mathrm{C}, 0$ & $\mathbf{F}$ & None \\
\hline fires & $2-10$ & $\begin{array}{l}\text { "Fire extinguishers will be } \\
\text { placed at several con- } \\
\text { spicuous locations on the } \\
\text { project site and 'no smoking' } \\
\text { signs will be located no } \\
\text { more than } 100 \mathrm{ft} \text { from the } \\
\text { drilling rig and production } \\
\text { facilities." }\end{array}$ & $\mathrm{C}, 0$ & $\begin{array}{l}\text { Signs installed; fire } \\
\text { extinguishers installed } \\
\text { in October } 1982 .\end{array}$ & None \\
\hline casing failure & $2-11$ & $\begin{array}{l}\text { "The monitoring wells will } \\
\text { be sampled periodically } \\
\text { to detect leakage. .." }\end{array}$ & $\mathbf{0}$ & $\mathbf{F}$ & None \\
\hline blowout & $2-5$ & $\begin{array}{l}\text { "A rotary rig will be } \\
\text { installed with the neces- } \\
\text { sary blowout prevention } \\
\text { equipment." }\end{array}$ & $\mathbf{0}$ & $\mathbf{F}$ & None \\
\hline
\end{tabular}


Table 1. (Continued)

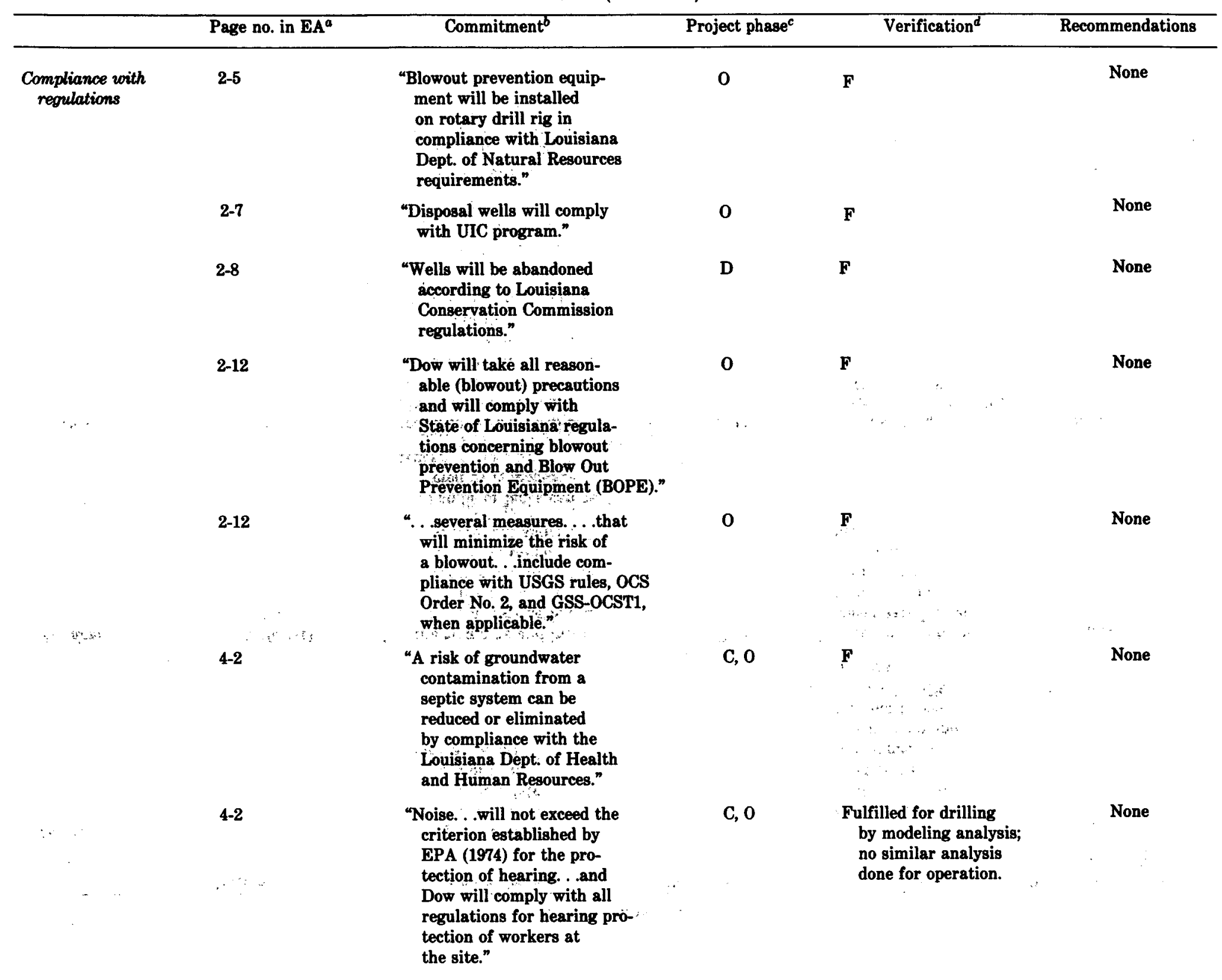



- Permanent disposal of drilling waste-The drilling waste was stored in a lined mud pit. In April 1983, as part of project decommissioning, the liquid in the mud pit was removed to an approved offsite disposal site. The sludge-like material remaining in the bottom of the pit was analyzed by Southern Petroleum Laboratory. Results indicated the presence of potentially toxic substances such as lead, chromium, and cadmium.

The sludge analysis data were subsequently reviewed by Gulf Coast Agricultural Associates, Inc., who stated that the levels of the potentially toxic compounds in the sludge do not preclude its use as a soil amendment for pastureland (Storm, 1983). Therefore, at the land owner's request, the sludge in the pit was pumped to a pasture located to the east of the brine pit. The sludge was spread over the land and disked into the soil, and the pasture was reseeded. Although the torn mud pit liner provided a pathway for the transport of substances from the pit to the environment, the impacts were minimal in the context of the intended use of the land.

- Fire extinguishers-During the August 1982 visit, no fire extinguishers were located in the immediate vicinity of either the disposal well or the test well. The nearest extinguishers were in the trailers used as offices and a laboratory located about $150 \mathrm{~m}$ $(500 \mathrm{ft})$ from the wells. In October 1982, an extinguisher was installed in a small utility shed between the production and disposal wells.

- Noise impacts-Operational noise appeared to be minimal; the major noise source at the well was the diesel generator, and it was located about $0.8 \mathrm{~km}(0.5 \mathrm{mi})$ from the nearest residence to minimize its impact. A noise-modeling analysis conducted for the EA determined that noise levels produced by well drilling, which is the noisiest phase of geopressure development, did not exceed levels established by the Environmental Protection Agency (EPA) (EPA, 1974).

- Environmental monitoring-The Environmental Monitoring Plan described in Appendix A of the EA was followed except that air quality monitoring was performed for only a short time during well testing, and water quality monitoring was not conducted on a monthly basis. The major reason for suspending the air quality monitoring was a lack of funds, coupled with the low potential of the project for air quality deterioration (Van Sickle, 1982b). Additional air monitoring should have been conducted because of the potential for gas release during flow testing. Additional analyses of the air quality data should be performed to determine whether any statistically significant changes in air quality occurred during well construction and well testing.

The EA stated that groundwater monitoring would be conducted at least monthly to detect possible contamination from the well testing. This was temporarily suspended because of funding cutbacks and a lack of significant change in the results of monthly samples. As a result, surface water and groundwater have been sampled on a quarterly basis, even following decommissioning. After two years of water quality sámpling, which included a period of well testing, it was concluded that quarterly sampling was sufficient because the baseline data clearly established seasonal trends in the parameters of interest. Part III of the Environmental Monitoring Plan allowed for this change in frequency of sampling. Several samples of groundwater and surface water would have been taken in the event of an accident, such as a major spill or blowout. 


\subsubsection{Monitoring Activities}

This section reviews the adequacy of air, noise, water, ecological, and geological monitoring at the Dow well site. The Louisiana Geological Survey and LSU conducted all environmental monitoring at the Dow well, either directly or through the use of subcontractors.

\subsubsection{Air quality}

According to Appendix A of the EA for the Dow well (DOE, 1980a), the air quality monitoring baseline studies at the well had the following goals:

- to determine ambient air quality prior to possible disturbance from test well activities;

- to identify any substance potentially derived from the geopressure fluid that might have an adverse effect on the environment and to establish baseline concentrations;

- to collect locally available meteorological data necessary for understanding dispersion and conversion patterns; and

- to provide baseline data compatible with later measurements needed to ensure compliance with state and federal ambient air quality standards.

Air quality and meteorological monitoring were evaluated relative to attainment of program objectives and the use of appropriate parameters, techniques, frequency of sampling, and duration of sampling.

Ambient air quality and meteorology were monitored by KEMRON Environmental Services, under subcontract to LSU, from July 1, 1980, through October 31, 1981. The monitoring station was located approximately $47.8 \mathrm{~m}(1600 \mathrm{ft})$ northwest of the production well, as shown in Fig. 2, and was sited according to EPA criteria and guidelines (Van Sickle, 1982a). The station provided continuous records of $\mathrm{H}_{2} \mathrm{~S}, \mathrm{SO}_{2}$, nonmethane hydrocarbons (NMHC), total hydrocarbons (THC), wind speed, wind direction, temperature, and precipitation during the period of record.

The selection of pollutants to be monitored was consistent with the Environmental Monitoring Plan and was adequate to detect any potential impacts from development of the resource. The pollutants monitored were those most likely to be associated with the development of a geopressured geothermal resource. Under normal operation (i.e., excluding accidents such as well blowouts), the major potential for air quality degradation from a geopressure well is associated with treatment of the natural gas to meet pipeline specifications prior to sale (Goldsberry, 1980) or with flaring the gas. Gas treatment generally consists of dehydration and removing $\mathrm{H}_{2} \mathrm{~S}$ (sweetening). While this treatment removes the $\mathrm{H}_{2} \mathrm{~S}$ from the pipeline, the local atmospheric concentration can be increased as a result of leakage from the treatment system itself. An analysis of gas produced at the Dow well showed no $\mathrm{H}_{2} \mathrm{~S}$ (Keeley and Meriwether, 1982).

Flaring of all gas produced, as at the Dow well, probably emitted carbon monoxide, unburned hydrocarbons, $\mathrm{CO}_{2}$, aldehydes, and particulates (Klett and Galeski, 1976), and nitrogen oxides (Engineering Science, 1983). Any $\mathrm{H}_{2} \mathrm{~S}$ in the gas was probably oxidized to 


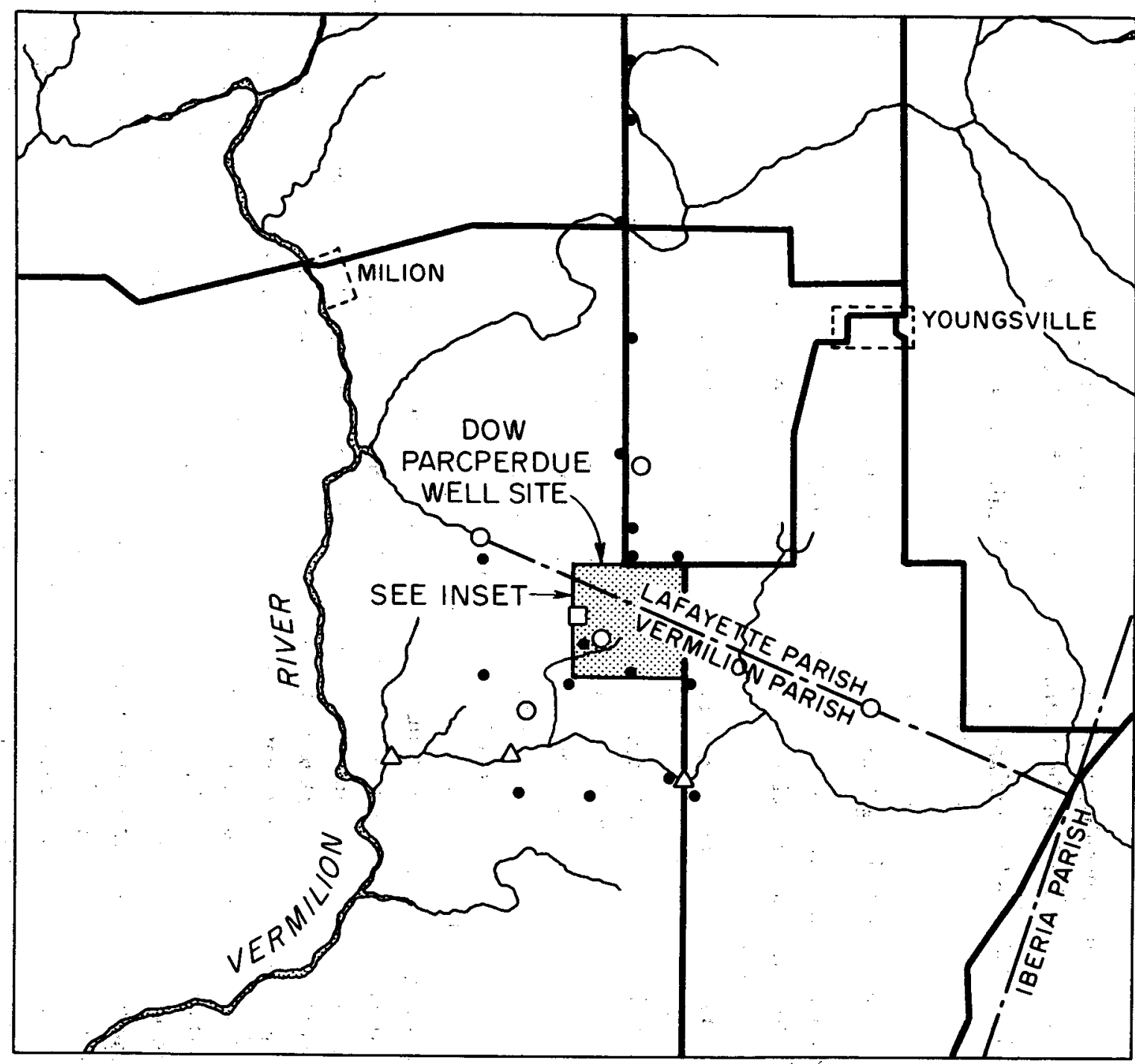

O SEISMOMETER

$\triangle$ SURFACE WATER SAMPLING STATION

口 AIR QUALITY MONITORING STATION

- BENCHMARK

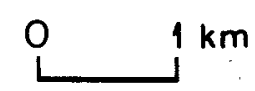

Fig. 2. Locations of field environmental monitoring stations near the Dow Parcperdue geopreasure
aign well. Source: Wrighton et al. (1981), Fig. 2.

INSET-SECTION 26

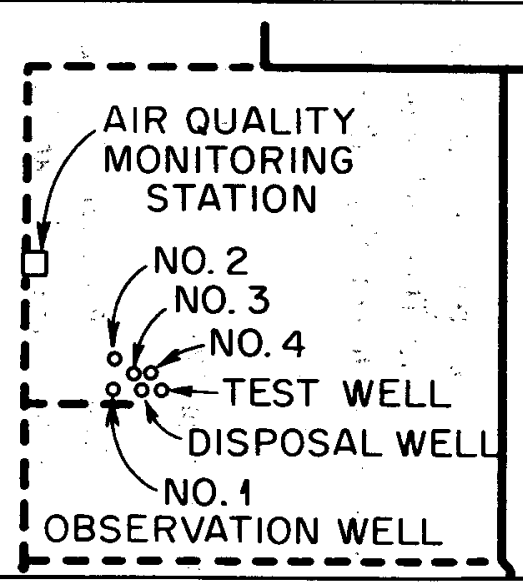


$\mathrm{SO}_{2}$ (Newchurch et al., 1979). The principal air impacts from flaring would have been increased ambient levels of the previously listed pollutants. Incremental increases in localized ambient pollutant levels from flaring were probably minimal, although the limited monitoring done during well operation made it difficult to confirm this prediction.

Less likely air quality impacts of operation could have resulted from the release of chemical constituents of the geopressure fluid. For potentially toxic compounds in a geopressure reservoir to be released to the environment during normal operations of a geopressure well, they must be present in the gaseous phase after the fluid passes through the separator. Burning of the gas in a flare onsite, or sale of the gas for combustion elsewhere, would then release these compounds to the atmosphere. Analyses of the gas at the Dow well did not reveal any compounds that could be considered toxic at low concentrations. Analyses of the Dow brine indicated that potentially harmful species were present. For example, boron, which was measured at concentrations of about $60 \mathrm{mg} / \mathrm{L}$ (Keeley and Meriwether, 1982), is thought to be potentially harmful to biota (Gustavson and McGraw, 1978). It is believed, however, that these species were confined to the brine and were reinjected via the disposal well.

Analytical procedures for air quality monitoring were consistent with designated reference or equivalent methods published by the EPA (EPA, 1980), and analyzer performance conformed to specifications for automated methods as described in $40 \mathrm{CFR}$ Parts 50 and 53 (Van Sickle, 1982a). Meteorological monitoring was consistent with procedures recommended by EPA guidelines (EPA, 1980). Quality assurance techniques for ambient air quality and for meteorological data were generally consistent with the EPA guidelines (Van Sickle, 1982a).

The frequency at which the ambient data were collected for all parameters was sufficient to allow analyses of both short- and long-term ambient air quality impacts. The 13-month length of the preoperational air monitoring baseline study is adequate. The EPA recommends that any preconstruction air quality monitoring be done for a minimum of one year; however, exceptions are granted, as long as the applicant can demonstrate that the shorter monitoring period will cover a period when maximum pollutant levels can be expected. In no case shall the period of monitoring be less than four months (EPA, 1980). Air monitoring prior to well construction was conducted for six to eight months; the period covered the time of year when the atmosphere does not favor pollutant dispersal and thus encourages high pollution levels (C. K. Geoenergy, 1980); thus, the EPA criteria were met. These requirements are largely related to permit requirements under the Clean Air Act as amended (PL 95-95) and may not be applicable to evaluating the environmental impacts of geopressure design wells under the regulations for implementing NEPA (43 FR 55978-56007). Nevertheless, the EPA guidelines reflect federal policy for conducting air quality and meteorological monitoring and are valuable to the monitoring program for the design wells.

Because of funding cutbacks and the low potential of the project for air quality degradation, air quality monitoring at the Dow well was terminated on October 31, 1981. No significant air quality impacts were detected in the 1.25 years of monitoring conducted, which covered baseline (preconstruction) air quality, air quality during well drilling, and air quality during limited short-term flow testing (conducted in October 1981) (C. K. Geoenergy, 1981a). More thorough data analyses are recommended following termination of the project. 


\subsubsection{Noise}

No noise monitoring was conducted at the Dow well (Van Sickle, 1982a); however; noise monitoring was not specified in the Environmental Monitoring Plan. In lieu of monitoring, noise modeling was performed to evaluate noise impacts resulting from activities at the site. Background noise levels were obtained from EPA guidelines (EPA; 1974) based on existing land use in the area (DOE, 1980a). The noisiest phase of geopressure development is well drilling; consequently, the impacts of well drilling were evaluated using a modeling analysis conducted at the Pleasant Bayou geopressure well site (Gustavson, 1979). The analysis showed that orientation of the noisy side of the drilling rig away from sensitive receptors would result in ambient noise levels within those recommended by the EPA. Any noise impacts from well operation would be thess than those from drilling (Van Sickle, 1982a). Because the site visit to the Dow well was conducted long after drilling was completed, verification of this mitigation measure was not possible. The noisiest aspect of well operation observed during the site visit was the operation of the diesel generators. These were located away from the Sweezy residence (the nearest receptor) to minimize noise impacts.

\subsubsection{Water quality}

Monthly monitoring of surface water and groundwater quality was initiated at the Dow site in January 1980. Because of funding cutbacks and no significant change in the results of monthly samples, surface water and groundwater quality has subsequently been sampled quarterly. LeBlanc Ditch, which received all runoff from the site area; was monitored at two stations west of the test well and one station east of the well (Fig. 2). Groundwater monitoring on the site was initially accomplished using 15- and 30-m- (40- and 100-ft-) deep wells originally drilled by the landowner; these were replaced by a $55-\mathrm{m}$ - (180-ft-) deep sampling well (No. 1, Fig. 2) and a 40-m- (130-ft-) deep potable water supply well (No. 3, Fig. 2). Sampling of surface water and groundwater indicated seasonal variation in water quality but no alteration that was attributed to the test well (Bebout et al., 1982).

In evaluating the water quality monitoring, consideration was given to the adequacy of (1) sampling locations, (2) frequency of monitoring, (3) choice of water quality constituents monitored, and (4) presentation and interpretation of results. The monitoring program for the Dow site appears capable of revealing significant changes in water quality resulting from well operations. The reporting of monitoring data could be improved through discussion and interpretation by comparison with appropriate water quality criteria (e.g., "Water Quality Criteria for Toxic Substances," 45 FR 79318-79) : and by comparison with typical concentrations for the region.

\subsubsection{Ecology}

The only ecological work at this site consisted of a review of existing literature to estimate baseline conditions. No actual monitoring of the site and surroundings was conducted. Because of the existing disturbed condition of the ecosystem in the vicinity of the 
well, no ecological monitoring was recommended. In the event of a blowout or other major spill, monitoring of biota or of effects on aquatic or terrestrial habitat might have been needed.

\subsubsection{Subsidence and microseismicity}

A first-order leveling survey was conducted at the Dow site prior to well drilling. In addition, existing benchmarks in the vicinity of the site were releveled between drilling and testing of the well. To detect subsidence, the system was designed to permit comparisons of relative elevations before and after reservoir drawdown. Preliminary calculations indicated that subsidence from single wells would be minor and overshadowed by effects from oil production (Cotter, 1982). Nevertheless, detection of subsidence and earth tremors resulting from testing is very important, not only from the standpoint of estimating the potential effects of future geopressure development, but also in relation to other activities.

Five borehole seismometers have been operated continuously around the site to determine the origin and magnitude of local microseismic events. None of those detected could be clearly ascribed to drilling and production, but the network did detect seismicity related to a recent earthquake in the New Iberia area and to the collapse of the Jefferson Island salt mine (C. K. Geoenergy, 1981b). Both for geopressure development and for regional concerns, microseismic monitoring should be continued for at least one year after the end of production testing.

\subsubsection{Decommissioning}

During decommissioning, the land was restored to a condition agreed upon by DOE and the owner of the property. The Dow EA stated that after flow testing was completed, the entire site area would be returned to its original condition unless some other written agreement were made with the owner. Dow met the decommissioning commitments listed in the environmental checklist (Sect. 3) (Storm, 1983).

\subsection{Sweet Lake}

The goals of the Sweet Lake project are to drill, complete, and test one geopressure well in Cameron Parishh on a 2-ha (5-acre) test site, $23 \mathrm{~km}$ (14 mi) southwest of Lake Charles, Louisiana, and to drill one disposal well. Tests conducted include flow rates, fluid composition, temperature, gas content, geological characteristics, and the land subsidence potential. One geopressured zone at a depth of about $4,600 \mathrm{~m}(15,000 \mathrm{ft})$ was tested for about six months. The well production (brine) averaged about $10,000 \mathrm{bbl} / \mathrm{d}$, with about 0.54 to 0.62 $\mathrm{m}^{3}$ (19 to $22 \mathrm{scf}$ ). of gas per barrel. In February 1982 a leak was detected in the 0.14-m (5-1/2-in.) tubing in the production well. The well was shut-in until July 1983, at which time DOE directed the contractor to proceed with repairs. The leak will be patched, the production well will be cleaned out, and another zone will be perforated for testing (DOE, 1983). 


\subsubsection{Commitment Checklist}

This study verifies the environmental mitigation and monitoring commitments that were made in the EA (DOE, 1980b) for the Sweet Lake well. The basis for the evaluation is a checklist of the mitigation and monitoring commitments in the EA; as summarized in Table 2. The operations at the Sweet Lake well were examined on August 11, 1982, by onsite inspection. Several items require discussion is addition to the checklist.

- Water resource impacts-All drilling muds at the Sweet Lake site were contained in tanks and hauled offsite by the drilling contractor (Berning, 1982a). Brine that could not be reinjected was stored in large blowdown tanks that were emptied by vacuum trucks. High-pressure pipes and valves were used on the casing, in accordance with the Louisiana Department of Cónservation Surface Casing Program (Berning, 1982a).

- Air quality impacts-The commitments to minimize air quality impacts during well construction (i.e., road surfacing) were verified by inspection of aerial photographs.

- Noise impacts-Verifying implementation of noise impact mitigation measures during construction and drilling was not possible. During the site visit, the well was not operating, so it was impossible to evaluate the noise generated during operation.

\subsubsection{Monitoring Activities}

This section reviews the adequacy of air, noise, water, ecological, and geological monitoring activities at the Sweet Lake well site. It also makes recommendations for further monitoring where deemed necessary. LSU conducted all environmental monitoring at the Sweet Lake site, either directly or through the use of subcontractors.

\subsubsection{Air quality}

A fixed, automated ambient air quality and meteorological monitoring station was installed and operated approximately $0.6 \mathrm{~km}(1 \mathrm{mi})$ northwest of the production well site (Fig. 3), by Core Laboratories, Inc., of Lake Charles, Louisiana, under subcontract to LSU (Bebout et al., 1982). Continuous monitoring of the following parameters was conducted from July 1, 1980, through May 31, 1982: $\mathrm{H}_{2} \mathrm{~S}, \mathrm{SO}_{2}, \mathrm{NMHC}$, THC, wind speed, wind direction, and precipitation.

The objectives of the air quality monitoring program at Sweet Lake are identical to those at Dow (Sect. 3.1.2.1). This section evaluates the air monitoring program conducted at Sweet Lake based on attainment of the program objectives and on the following criteria: monitoring of appropriate parameters, use of appropriate techniques, monitoring at appropriate frequencies, and duration of monitoring activity.

Under normal operation, the greatest potential for air quality degradation from a geopressure well is associated with the handling of the natural gas produced, depending on whether the gas is flared or treated for removal of pollutants (Goldsberry, 1980). A smaller pollution potential from brine handling may exist, especially in the case of accidents. The potential air pollutants that should be monitored are those in the gas plus those which could 
Table 2. Mitigation and monitoring commitment checklist for the Sweet Lake No. 1 geopressure design well, Cameron Parish, Louisians

\begin{tabular}{|c|c|c|c|c|c|}
\hline & $\begin{array}{l}\text { Document/ } \\
\text { page no. }{ }^{a}\end{array}$ & Commitment $^{b}$ & Project phase $^{c}$ & Verification $^{d}$ & Recommendations \\
\hline $\begin{array}{l}\text { General site } \\
\text { preparation }\end{array}$ & EA/1-17 & $\begin{array}{l}\text { "Existing roads will be used } \\
\text { so as not to impact new } \\
\text { areas; upgrading access } \\
\text { routes will be restricted to } \\
\text { essential activities; activi- } \\
\text { ties will be limited to } \\
\text { seasons when wildlife or } \\
\text { land uses will be least } \\
\text { affected. . .will keep area } \\
\text { required to minimum by } \\
\text { using smallest feasible } \\
\text { drill rig and facilities } \\
\text { configuration. . . A ring levee } \\
\text { will be constructed around } \\
\text { the entire drill pad." }\end{array}$ & C & $\begin{array}{l}\text { F; road and levee } \\
\text { commitments } \\
\text { verified by inspec- } \\
\text { tion of aerial } \\
\text { photographs taken } \\
\text { during construction }\end{array}$ & None \\
\hline $\begin{array}{l}\text { Land resoures } \\
\text { erosion }\end{array}$ & EA/1-17 & $\begin{array}{l}\text { "Drill pads and roads will be } \\
\text { surfaced with shell to } \\
\text { retard runoff. Barriers will } \\
\text { be installed to contain } \\
\text { runoff and prevent erosion." }\end{array}$ & $\mathrm{C}$ & $F$ & None \\
\hline \multirow[t]{2}{*}{$\begin{array}{r}\text { Water resources } \\
\text { surface water }\end{array}$} & EA/3-3 & $\begin{array}{l}\text { "Contaminants will be contained } \\
\text { by levees surrounding the } \\
\text { well which will be con- } \\
\text { structed in accordance } \\
\text { with State regulations." }\end{array}$ & $\mathrm{C}, \mathrm{O}$ & $\mathrm{F}$ & None \\
\hline & EA/3-5 & $\begin{array}{l}\text { "Drilling muds and associated } \\
\text { chemicals will be reinjected } \\
\text { before the site is abandoned." }\end{array}$ & O, D & $\begin{array}{l}\text { F; muds were removed } \\
\text { from site for } \\
\text { reuse or disposal. }\end{array}$ & None \\
\hline (groundwater) & EA/1-18, 3-3 & $\begin{array}{l}\text { “. .use of high pressure pipes } \\
\text { and valves and will seal } \\
\text { off aquifers following LA } \\
\text { [Louisiana] Dept. of } \\
\text { Conservation surface } \\
\text { casing program." }\end{array}$ & 0 & $F$ & None \\
\hline $\begin{array}{l}\text { Air quality } \\
\text { fugitive dust }\end{array}$ & EA/1-18 & $\begin{array}{l}\text { ". . roads and drilling pads } \\
\text { will be surfaced with } \\
\text { boards and shells." }\end{array}$ & $\mathrm{C}, \mathrm{O}$ & $\mathrm{F}$ & None \\
\hline
\end{tabular}


Table 2. (Continued)

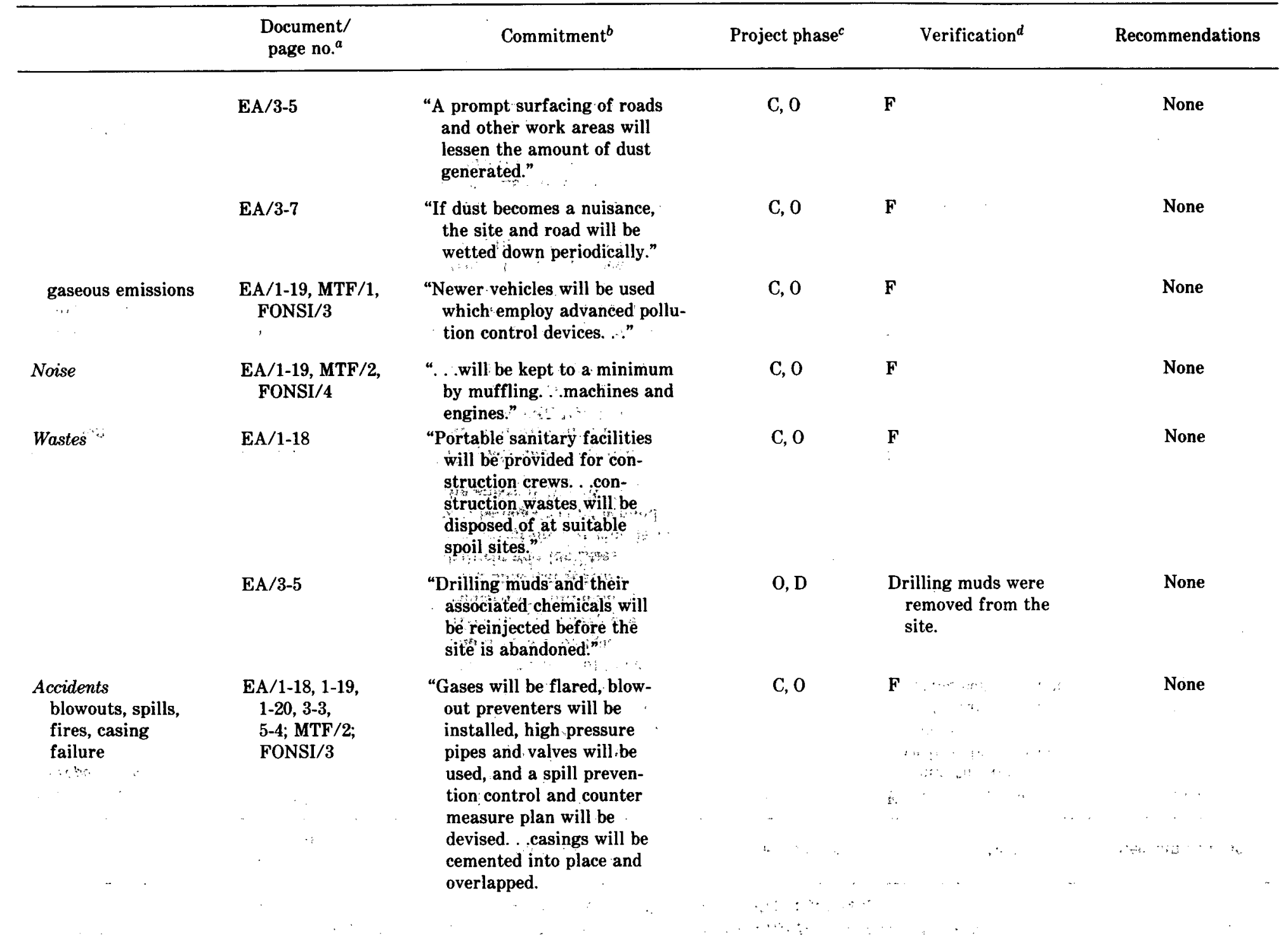


Table 2. (Continued)

\begin{tabular}{|c|c|c|c|c|c|}
\hline & $\begin{array}{c}\text { Document/ } \\
\text { page no. }\end{array}$ & Commitment $^{b}$ & Project phase $^{c}$ & Verification $^{d}$ & Recommendations \\
\hline \multirow[t]{5}{*}{$\begin{array}{l}\text { Compliance with } \\
\text { regulations }\end{array}$} & EA/1-6 & $\begin{array}{l}\text { "The EPA Underground Injection } \\
\text { Control Program proposed } \\
\text { rules apply to both geo- } \\
\text { thermal and injection wells } \\
\text { and will be complied with } \\
\text { once they become effective." }\end{array}$ & 0 & $\mathbf{F}$ & None \\
\hline & EA/3-3 & $\begin{array}{l}\text { “. surface casing program } \\
\text { required by rules and } \\
\text { regulations of the } \mathrm{LA} \\
\text { Dept. of Conservation. .." }\end{array}$ & 0 & $\mathbf{F}$ & None \\
\hline & EA/5-1 & $\begin{array}{l}\text { "OSHA guidelines protect } \\
\text { worker health and welfare } \\
\text { at the site of the } \\
\text { proposed action." }\end{array}$ & C, $0, D$ & $\mathbf{F}$ & None \\
\hline & EA/5-4 & $\begin{array}{l}\text { "Well design and drilling plans } \\
\text { will be reviewed by the } \\
\text { LA Dept. of Natural } \\
\text { Resources as a prelude } \\
\text { to their issuance of } \\
\text { a permit to drill." }\end{array}$ & Preoperation & $\mathbf{F}$ & None \\
\hline & EA/5-12 & $\begin{array}{l}\text { "Operational blowout preven- } \\
\text { ters are required by the } \\
\text { rules and regulations of } \\
\text { the LA Dept. of } \\
\text { Conservation." }\end{array}$ & 0 & F & None \\
\hline \multirow[t]{2}{*}{ Monitoring program } & EA/1-12 & $\begin{array}{l}\text { "An Environmental monitoring } \\
\text { program (Appendix A) will } \\
\text { be implemented as part } \\
\text { of the project." }\end{array}$ & $\begin{array}{l}\mathrm{PC} \\
\quad \mathrm{C}, \mathrm{O}, \mathrm{D}\end{array}$ & $\mathbf{F}$ & None \\
\hline & EA/3-8, 3-17 & $\begin{array}{l}\text { "An air quality monitoring } \\
\text { program will be imple- } \\
\text { mented during the 60-day } \\
\text { test." }\end{array}$ & 0 & $F$ & None \\
\hline
\end{tabular}


Table 2. (Continued)

\begin{tabular}{|c|c|c|c|c|c|}
\hline & $\begin{array}{l}\text { Document/ } \\
\text { page no.a }\end{array}$ & Commitment $^{b}$ & Project phase ${ }^{c}$ & Verification $^{d}$ & Recommendations \\
\hline \multirow[t]{2}{*}{ Decommissioning } & $\mathrm{EA} / 1-16$ & $\begin{array}{l}\text { "The wells will be plugged } \\
\text { according to the regula- } \\
\text { tions and permits of the } \\
\text { LA Dept. of Conservation." }\end{array}$ & DC & NV & $\begin{array}{l}\text { Conduct site visit } \\
\text { after decommis- } \\
\text { sioning to verify. }\end{array}$ \\
\hline & EA/1-16 & $\begin{array}{l}\text { "All surface facilities will } \\
\text { be removed; all refuse, } \\
\text { garbage, and toxic } \\
\text { materials will be cleaned } \\
\text { from the area; and the } \\
\text { sites will be returned } \\
\text { to a condition similar } \\
\text { to the original." }\end{array}$ & $\mathrm{DC}$ & NV & $\begin{array}{l}\text { Contact landowner } \\
\text { after completion; } \\
\text { conduct site visit. }\end{array}$ \\
\hline
\end{tabular}

${ }^{a}$ Reference documents: Environmental Assessment [EA (DOE, 1980b)]; memo to file (MTF) and finding of no significant impact (FONSI) (Clusen, 1980b).

${ }^{b}$ Directly quoted from the EA (DOE, 1980b).

${ }^{c} \mathrm{C}=$ construction; $\mathrm{D}=$ decommissioning; $\mathrm{O}=$ operation; $\mathrm{PC}=$ preconstruction.

${ }^{d}$ As determined by onsite inspection, August 11,$1982 ; \mathrm{F}=$ fulfilled; $\mathrm{NV}=$ not verifiable. 
ORNL-DWG 82-20681

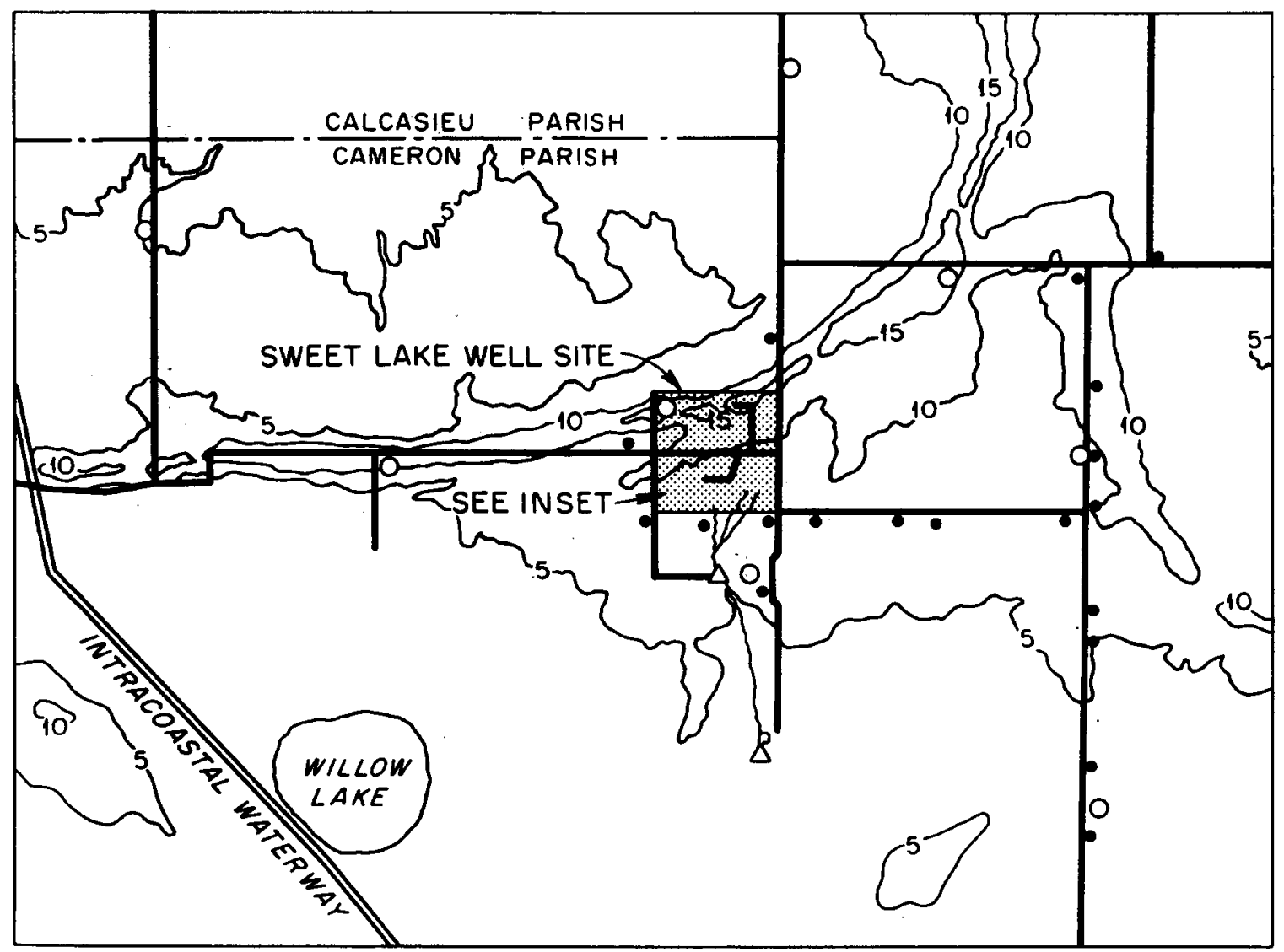

$\triangle$ SURFACE WATER SAMPLING STATION

O SEISMOMETER

- beNCHMARK
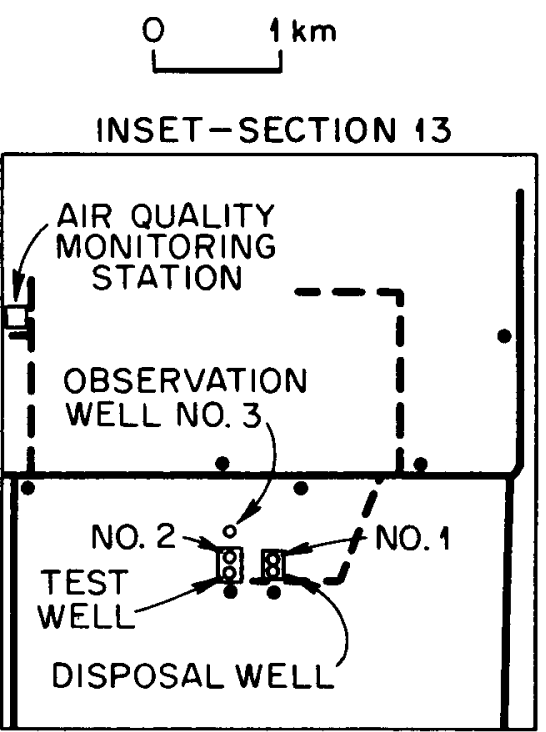

Fig. 3. Locations of field environmental monitoring stations near the Sweet Lake No. 1 geopressure design well. Source: Bebout et al. (1982), Fig. 12. 
be formed during the gas treatment/disposal process. Analyses of the gas collected at Sweet Lake indicate the following composition (values are mole percentages unless otherwise noted): $89 \%$ methane, $1.7 \%$ ethane, $0.7 \%$ propane and higher hydrocarbons; $0.2 \% \mathrm{~N}, 8.6 \%$ $\mathrm{CO}_{2}$, and 15 to 30 parts per million by volume (ppmV) $\mathrm{H}_{2} \mathrm{~S}$ (Durrett; 1981). Of these, the ethane, propane, and higher hydrocarbons and the $\mathrm{H}_{2} \mathrm{~S}$ are potential pollutants that might not burn if the gas were flared. It may be possible to recover ethane and propane for subsequent sale. Sulfur dioxide $\left(\mathrm{SO}_{2}\right)$, resulting from the oxidation of $\mathrm{H}_{2} \mathrm{~S}$ in a flare, is a fourth potential pollutant: (Newchurch et al., 1979). Flaring produces unburned hydrocarbons, oxidized hydrocarbons (e.g., aldehydes), $\mathrm{SO}_{2}, \mathrm{CO}$, and particulate matter (Klett and Galeski, 1976). In terms of air pollution from handling natural gas, it appears that the Sweet Lake monitoring program dealt with the appropriate potential air pollutants; the small amount of particulates and CO produced during flaring does not justify monitoring these pollutants.

All air pollutants were monitored using methods approved by EPA (40 CFR Parts 50 and 53), and meteorological monitoring conformed to EPA guidelines (EPA, 1980). The monitoring station was sited using techniques approved by the EPA, and"data reduction and quality assurance were performed in conformance with EPA guidelines (EPA, 1980). The frequency at which the ambient data were collected for-all parameters was sufficient to allow both short- and long-term analyses of ambient air quality impacts.

Construction at the Sweet Lake site began around November 1980 (Berning, 1982a); data were collected for approximately four months prior to construction. Based on meteorological data representative of the general area of the well site (data collected at Lake Charles), the period from November through March has a good potential for high pollutant levels, primarily because of low mixing heights (DOE, 1980b). Thus, the particular four-month period during which monitoring was conducted prior to construction probably characterized baseline concentrations during periods of high pollution, except perhaps near the end of the monitoring period. Air monitoring continued during well construction and during flow testing. The total data base collected ( 22 months) should be adequate to assess the air quality impacts of geopressure well testing at the Sweet Lake site.

In summary, the air monitoring program conducted at the Sweet Lake well appears adequate to address most air quality concerns associated with geopressure development. No adverse air quality impacts that could be attributed to the well activity were detected by the monitoring data. At the end of the monitoring activity, the data analysis should address whether or not statistically significant changes in air quality occurred during different phases of geopressure development (construction, drilling, and testing).

\subsubsection{Noise}

According to the Sweet Lake Environmental Monitoring Plan (DOE, 1980b), a baseline ambient noise level survey was to have been conducted prior to site development. Additional noise level surveys were to be reported as decibels on the A-weighted sound level scale. Noise surveys were to provide both the sound level that was exceeded $10 \%$ of the time during each measurement period, $L_{10}$, and the equivalent continuous level, $L_{e q}$. Noise level meters were to conform to Type 2-General Purpose specifications (\$1.4) for accuracy established by the American National Standards Institute. 
No noise monitoring program was conducted at the Sweet Lake site (Van Sickle, 1982a). The primary reason for not monitoring noise was the project's low potential for long-term adverse noise impacts, as indicated by noise studies conducted at the Pleasant Bayou well site in Texas (Gustavson, 1979). The analysis at the Pleasant Bayou site showed that well drilling, which is the noisiest phase of geopressure development, would not exceed EPA noise level criteria for the protection of human health (EPA, 1974). This was confirmed by noise-modeling analysis and by actual field measurements of an operating drill rig (see Sect. 3.4.2.2). Noise during well testing was assumed not to be significant because of the benign nature of the process; that is, the major noise source is likely to be a diesel generator. If onsite power is available and if the gas is sold, there are virtually no major noise sources at the well site.

\subsubsection{Water quality}

Monitoring of surface water quality was initiated at the Sweet Lake site in May 1980, and groundwater monitoring was begun in October 1980. Sampling continued on a monthly basis until June 1983, when quarterly sampling was initiated (Van Sickle, 1983). Surface water sampling stations were established at Precht Road, where surface water drainage from the site converges; at the inlet of Square Lake; and in the middle of Sweet Lake (Fig. 3). Groundwater is sampled at three wells near the test well (inset to Fig. 3).

Sampling of surface water to date has indicated seasonal variation in water quality and a gradient in concentrations between the fresh water at Precht Road and the brackish water at the sampling stations closer to the Gulf of Mexico. Sampling from the groundwater wells has indicated differences in water quality between the shallower wells, Nos. 1 and 2 [85 m

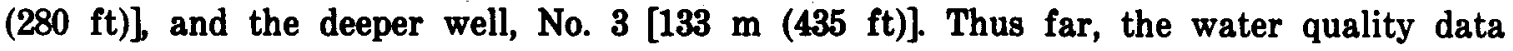
indicate no contamination from the geothermal well (Bebout et al., 1982).

In evaluating the water quality monitoring, consideration was given to the adequacy of (1) sampling locations, (2) frequency of monitoring, (3) choice of water quality constituents being monitored, and (4) presentation and interpretation of results. The monitoring program for the Sweet Lake site appears quite capable of revealing any significant changes in water quality resulting from well operations. The program could be improved by discussing and interpreting the sampling results in comparison with appropriate water quality criteria (e.g., "Water Quality Criteria for Toxic Substances," 45 FR 79318-79) and in comparison with concentrations typical for the region. In particular, the concentrations of mercury observed in surface water are noteworthy because the maximum reported concentrations exceed the EPA criterion for protection of aquatic life by over a hundredfold.

\subsubsection{Ecology}

The ecology of the Sweet Lake site and surroundings was characterized prior to drilling. In addition, land loss within the entire Sweet Lake prospect [ca. $32 \mathrm{~km}^{2}$ (12 sq miles)] was estimated from comparison of older and more recent maps and photos, and the natural processes producing land loss in the prospect were studied (Van Sickle, 1982b). No other 
ecological monitoring has been performed. Because of the disturbed and agricultural nature of the area, no monitoring is recommended except, possibly, in the event of a blowout or other large spill. At the time of decommissioning, $\mathrm{DOE}$ should ensure that the site is adequately protected from erosion, and, if the well is to be abandoned, that the site is returned to a useful condition.

\subsubsection{Subsidence and microseismicity}

Subsidence and microseismic activity have been monitored at the Sweet Lake site using methods similar to those described for the Dow site (Sect. 3.1.2.5). Because the Sweet Lake fault block is much larger than that at Dow, eight rather than five borehole instruments are being used, and the aperture of the seismic array is larger. Continuation of the monitoring for at least one year after the well is producing is recommended because of the same regional and operational concerns as those described in Sect. 3.1.2.5.

\subsubsection{Decommissioning}

Future use and decommissioning of the Sweet Lake site are uncertain and partially dependent on the interpretation of test results obtained from the well. DOE's plans for the well call for complete site decommissioning, with wells plugged and abandoned, followed by whatever site monitoring is needed.

Alternatively, analysis and economic evaluation may indicate that the geopressured reservoir can be utilized. If natural gas production is sufficient and gas quality is high, a connection may be made with the nearest gas pipeline. Geothermal energy may also be used for agricultural drying, electrical generation, or other uses. The choices between further site development, mothballing, and site decommissioning will depend on many factors that are currently uncertain. Future environmental impacts are difficult to predict, as are monitoring and the mitigation efforts that will be appropriate.

Because the future use of the Sweet Lake site is uncertain and will remain uncertain for months to come, recommendations regarding decommissioning are premature at this time. If and when a decision is made to abandon the well, the planning for decommissioning should proceed, based on DOE's previous commitments, the legal requirements of the state of Louisiana, the site's condition, and any other relevant factors.

\subsection{Gladys McCall}

The Gladys McCall project, located near Grand Chenier, Cameron Parish, Louisiana, is intended (1) to test and evaluate procedures and equipment for drilling into geopressured-geothermal reservoirs and utilizing these resources and (2) to evaluate the potential of geopressured-geothermal resources in a portion of the Frio formation. The project initially used an abandoned well drilled for oil and gas exploration in 1970. After. unsuccessful attempts to reenter the original well, a new well was drilled to approximately $5,185 \mathrm{~m}^{\prime \prime}(17,000 \mathrm{ft})$, and an additional disposal-injection "well was drilled. Site 
development began in early 1981; in the spring of 1982 the drilling was completed to the design depth. After $10 \mathrm{~m} \mathrm{(30} \mathrm{ft)} \mathrm{of} \mathrm{the} \mathrm{production} \mathrm{well} \mathrm{tubing} \mathrm{was} \mathrm{perforated,} \mathrm{pressure} \mathrm{on}$ the casing increased because of a tubing leak at $3,046 \mathrm{~m}(9,992 \mathrm{ft})$. The tubing was removed and bad joints were replaced in the fall of 1982 . Before flow testing began, a leak was detected in the tubing string at $4,403 \mathrm{~m}(13,211 \mathrm{ft})$. Attempts to reseal the leak failed.

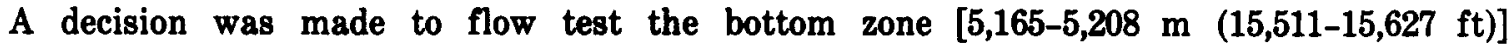
despite the problem. Tests begun on March 21, 1983, indicated an average production rate of $676 \mathrm{~m}^{3}(4250 \mathrm{bbl})$ of brine per day and $3,285 \mathrm{~m}^{3}\left(116,000 \mathrm{ft}^{3}\right)$ of gas per day. The temperature of the stabilized wellhead flow was $118^{\circ} \mathrm{C}\left(245^{\circ} \mathrm{F}\right)$ (C. K. Geoenergy, 1983a).

When flow testing was complete (May 1983), a cement plug was placed above the bottom zone in preparation for testing of an overlying zone. However, both the plug and the 0.13-m (5-in.) tubing sprung leaks, necessitating remedial action. During July 1983 a rig was brought in to pull the tubing and run new pipe into the well (DOE, 1983).

\subsubsection{Commitment Checklist}

The commitments for environmental monitoring and mitigation at the Gladys McCall test well are summarized in Table 3, and their verification is indicated. With few exceptions, the commitments have been fulfilled; in those cases where commitments have not been fulfilled, the most common reason was an unforeseen change in circumstances (as discussed below).

- Injection well-The regulations followed for drilling and completion of the injection well were the state of Louisiana's rules for Underground Injection Control (UIC) rather than EPA rules. EPA's final regulations for the UIC program, issued in February 1982, will be followed during the flow testing and other future operations.

- Onsite ponds and pits-The practices currently in use depart slightly from the commitments stated in the EA. Prior to site preparation, the Gladys McCall site contained a pond filled with mud from the original drilling of the well. The contents of this pond were trucked offsite for disposal, and the ring levee was raised. The pond now contains spent mud from the drilling of the geopressure wells. This pond lacks an impervious liner (e.g., a synthetic plastic liner), and the muds represent a potential source of trace element contamination to groundwater, soils, and plants. Research on mud pits at gas and oil well sites (see Appendix A) has indicated that mud pits containing lignosulfonate muds of the type used for geopressure wells are unlikely to cause major contamination of groundwater. However, localized contamination of soils and plants may result from leaching and uptake of heavy metals, and trace elements can in some cases leach from mud pits into groundwater (Dames and Moore, 1982).

It is recommended that the contents of the mud pit be disposed of or removed from the site rather than being allowed to remain for an extended period. This could occur as part of site decommissioning if the wells are abandoned within the next 6 to 12 months. However, if well testing or development is likely to continue more than 12 months, the muds should be disposed of in order to reduce the potential for environmental contamination. After the muds have been removed, soil samples should be analyzed to determine if any contamination has occurred. 
Table 3. Mitigation and monitoring commitment checklist for the Gladys McCall geopressure design well, Cameron Parish, Louisiana

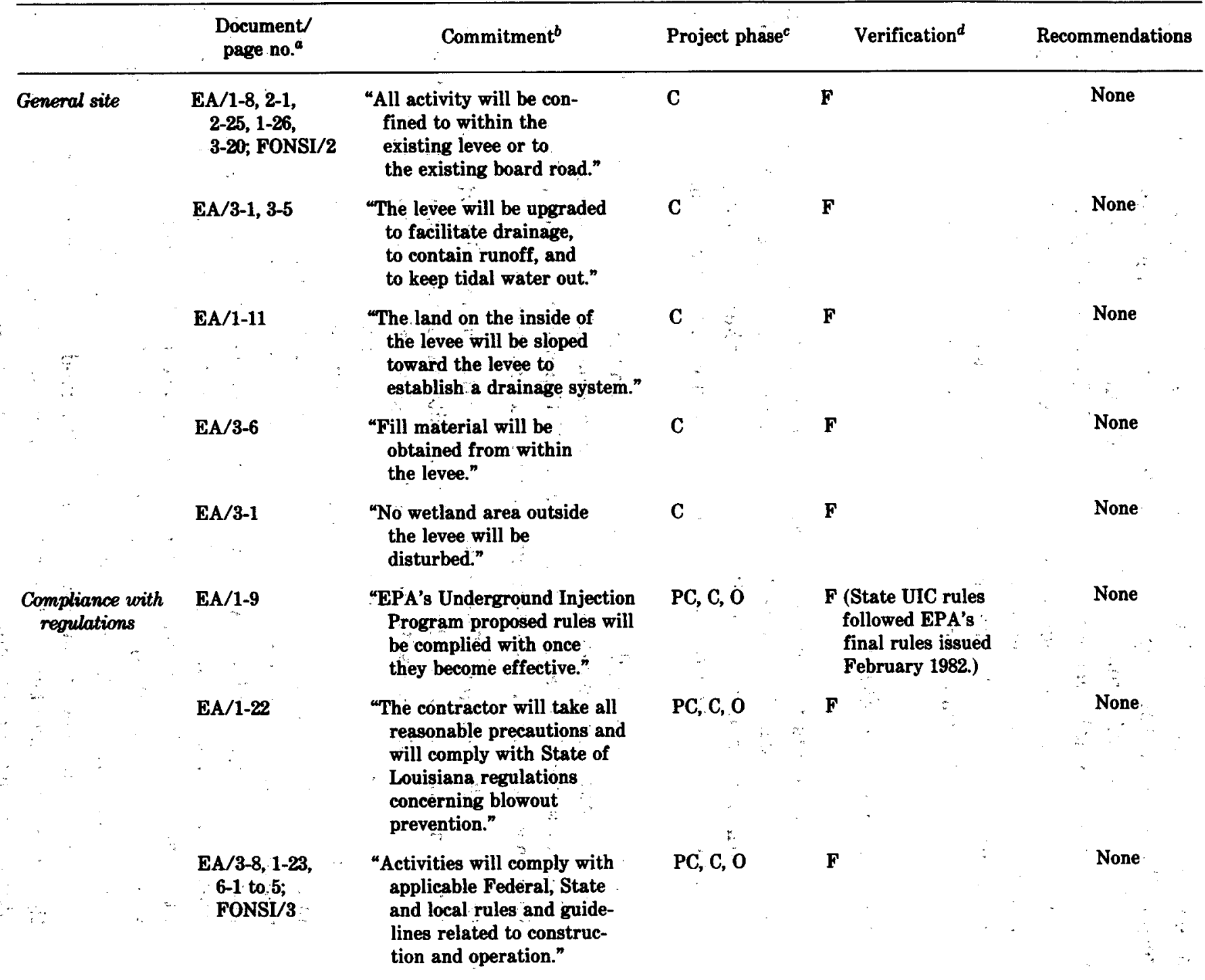


Table 3. (Continued)

\begin{tabular}{|c|c|c|c|c|c|}
\hline & $\begin{array}{l}\text { Document/ } \\
\text { page no. }\end{array}$ & Commitment $^{b}$ & Project phase ${ }^{c}$ & Verification $^{d}$ & Recommendations \\
\hline Noise & EA/1-24 & $\begin{array}{l}\text { "Noise will be minimized by } \\
\text { muffling machines and } \\
\text { engines." }\end{array}$ & $\mathrm{C}, 0$ & $\mathbf{F}$ & None \\
\hline Air quality & EA/1-23 & $\begin{array}{l}\text { "Newer vehicles will be used } \\
\text { which employ advanced } \\
\text { pollution control devices." }\end{array}$ & $\mathrm{C}, \mathrm{O}$ & $\mathbf{F}$ & None \\
\hline \multirow[t]{2}{*}{ Water } & EA/1-25 & $\begin{array}{l}\text { "Portable sanitary facilities } \\
\text { will be provided for con- } \\
\text { struction crews and wastes } \\
\text { will be transported to } \\
\text { suitable facilities." }\end{array}$ & $\mathrm{C}, 0$ & $\mathbf{F}$ & None \\
\hline & EA/1-25 & $\begin{array}{l}\text { "The reserve pond will be } \\
\text { lined with impervious } \\
\text { material to control infil- } \\
\text { tration and groundwater } \\
\text { contamination." }\end{array}$ & & $\begin{array}{l}\text { NF; pond is } \\
\text { unlined. }\end{array}$ & None \\
\hline \multirow[t]{3}{*}{ Spills and wastes } & EA/1-11 & $\begin{array}{l}\text { "Spilled fluids contained in } \\
\text { the diked area will be } \\
\text { pumped to a lined pit } \\
\text { for storage." }\end{array}$ & $\mathrm{C}, 0$ & $\begin{array}{l}\text { NF; pond is } \\
\text { unlined. }\end{array}$ & None \\
\hline & $\begin{array}{l}\text { EA/3-1, 3-2, } \\
\quad 3-21\end{array}$ & $\begin{array}{l}\text { "Spills will be contained in } \\
\text { the diked area, collected } \\
\text { and pumped into the dis- } \\
\text { posal well or transported } \\
\text { to an approved disposal } \\
\text { site." }\end{array}$ & $\mathrm{C}, 0$ & $\mathbf{F}$ & None \\
\hline & $\mathrm{EA} / 5-6$ & $\begin{array}{l}\text { "Surfactants will not be } \\
\text { used to clean up spills." }\end{array}$ & $\mathrm{C}, 0$ & $\mathbf{F}$ & None \\
\hline Storms & EA/3-21 & $\begin{array}{l}\text { "Project activities will be } \\
\text { scheduled to avoid poten- } \\
\text { tial problems associated } \\
\text { with major storms. In the } \\
\text { event of a major storm, } \\
\text { all equipment and hazardous } \\
\text { material will be secured } \\
\text { or removed from the site." }\end{array}$ & PC, C, 0 & $\begin{array}{l}\text { Scheduling has been } \\
\text { affected by project } \\
\text { delays. }\end{array}$ & None \\
\hline
\end{tabular}


Table 3. (Continued)

\begin{tabular}{|c|c|c|c|c|c|}
\hline & $\begin{array}{l}\text { Document/ } \\
\text { page no." }\end{array}$ & Commitment $^{b}$ & Project phase $^{c}$ & Verification $^{d}$ & Recommendations \\
\hline \multirow[t]{2}{*}{ Drilling } & EAT/3-6 & $\begin{array}{l}\text { "Nontoxic drilling muds will } \\
\text { be used." }\end{array}$ & C & $\mathbf{F}$ & None \\
\hline & EA/1-15, 3-6 & $\begin{array}{l}\text { "Drilling muds and chemicals } \\
\text { will be reinjected." }\end{array}$ & $\mathrm{C}$ & $\begin{array}{l}\text { NF; some drill- } \\
\text { ing muds and } \\
\text { chemicals have } \\
\text { been removed } \\
\text { from site. }\end{array}$ & $\begin{array}{l}\text { Remaining muds } \\
\text { and chemicals should } \\
\text { be removed or } \\
\text { reinjected. }\end{array}$ \\
\hline \multirow[t]{3}{*}{ Upon completion } & EA/3-6, 1-18 & $\begin{array}{l}\text { "All equipment and facilities } \\
\text { will be removed." }\end{array}$ & DC & NV & $\begin{array}{l}\text { Conduct site } \\
\text { visit after } \\
\text { decommissioning. }\end{array}$ \\
\hline & & $\begin{array}{l}\text { Wastes not injected will be } \\
\text { disposed of in a proper } \\
\text { landfill. }\end{array}$ & $\mathrm{DC}$ & NV & $\begin{array}{l}\text { Verify after } \\
\text { decommissioning. }\end{array}$ \\
\hline & & $\begin{array}{l}\text { Pit liners will be } \\
\text { removed. The board and } \\
\text { plastic matting of the pad } \\
\text { will be removed and } \\
\text { properly disposed of. }\end{array}$ & DC & NV & $\begin{array}{l}\text { Conduct site } \\
\text { visit after } \\
\text { decommissioning. }\end{array}$ \\
\hline \multirow[t]{5}{*}{ Accidents } & $\begin{array}{l}\text { EA/1-23 to } 25, \\
5-4 ;\end{array}$ & $\begin{array}{l}\text { "Blowout preventers will be } \\
\text { installed." }\end{array}$ & C & $\mathbf{F}$ & None \\
\hline & FONSI/3 & $\begin{array}{l}\text { High pressure pipes and } \\
\text { valves will be used: }\end{array}$ & C & $\mathbf{F}$ & None \\
\hline & EA/1-25, 5-4 & $\begin{array}{l}\text { "A spill prevention control } \\
\text { and countermeasure plan } \\
\text { will be developed for the } \\
\text { project." }\end{array}$ & $\mathbf{P C}$ & $\mathbf{F}$ & None \\
\hline & EA/5-13 & $\begin{array}{l}\text { "Abandonment records of all } \\
\text { nearby wells will be } \\
\text { checked to insure adequate } \\
\text { plugs.". }\end{array}$ & PC & $\mathbf{F}$ & None \\
\hline & EA/1-23, 1-26 & $\begin{array}{l}\text { "A safety plan and accident } \\
\text { prevention plan will be } \\
\text { devised by the contractor } \\
\text { and approved by DOE." }\end{array}$ & PC & $\mathbf{F}$ & None \\
\hline
\end{tabular}


Table 3. (Continued)

\begin{tabular}{|c|c|c|c|c|c|}
\hline & $\begin{array}{l}\text { Document/ } \\
\text { page no. }\end{array}$ & Commitment $^{b}$ & Project phase $^{c}$ & Verification $^{d}$ & Recommendations \\
\hline & $\mathrm{EA} / 1-19,1-20$ & $\begin{array}{l}\text { "Fire extinguishers will be } \\
\text { placed at several con- } \\
\text { spicuous locations on } \\
\text { site. } \\
\text { "No Smoking' signs will be } \\
\text { located no more than } \\
100 \text { feet from the pro- } \\
\text { duction facility." }\end{array}$ & $\mathrm{C}, 0$ & $\mathbf{F}$ & None \\
\hline \multirow[t]{4}{*}{ Monitoring } & $E A / 1-4$ & $\begin{array}{l}\text { "The State of Louisiana Geologi- } \\
\text { cal Survey will monitor } \\
\text { noise and air quality } \\
\text { around the site and main- } \\
\text { tain a good system to detect } \\
\text { subsidence or tectonic } \\
\text { activity." }\end{array}$ & $\mathrm{C}, 0$ & $\begin{array}{l}\text { Noise and air } \\
\text { monitoring not } \\
\text { done; subsidence } \\
\text { fulfilled. }\end{array}$ & None \\
\hline & $\begin{array}{l}\text { EA/1-17, } \\
\text { Appendix A, } \\
\text { FONSI/4,5 }\end{array}$ & $\begin{array}{l}\text { "An environmental monitoring } \\
\text { plan will be implemented." }\end{array}$ & $\mathrm{PC}, \mathrm{C}, \mathrm{O}$ & $\mathbf{F}$ & None \\
\hline & EA/1-20 & $\begin{array}{l}\text { "Monitoring wells will be } \\
\text { sampled periodically to } \\
\text { detect casing failures } \\
\text { or leaks." }\end{array}$ & $\mathrm{C}$ & $\mathbf{F}$ & None \\
\hline & $\begin{array}{l}\text { EA/1-18, } \\
\text { Appendix A, } \\
\text { FONSI/4,5 }\end{array}$ & $\begin{array}{l}\text { "An environmental monitoring } \\
\text { plan will be used to } \\
\text { identify mitigation measures } \\
\text { and corrective actions to } \\
\text { be implemented to mini- } \\
\text { mize impacts." }\end{array}$ & $\mathrm{PC}, \mathrm{C}, \mathrm{O}$ & $\mathbf{F}$ & None \\
\hline
\end{tabular}


Table 3. (Continued)

\begin{tabular}{|c|c|c|c|c|}
\hline $\begin{array}{l}\text { Document/ } \\
\text { page no. }\end{array}$ & Commitment $^{b}$ & Project phase $^{c}$ & Verification $^{d}$ & Recommendations \\
\hline $\begin{array}{l}\text { EA/Appendix A, } \\
\text { FONSI/4,5 }\end{array}$ & $\begin{array}{l}\text { "A baseline and drilling/pro- } \\
\text { duction monitoring plan } \\
\text { will collect data } \\
\text { on air quality, water } \\
\text { quality, subsidence, seis- } \\
\text { micity, and eco-system } \\
\text { quality as outlined in } \\
\text { the plan. } \\
\text { "The program will be conducted } \\
\text { by the contractor. The con- } \\
\text { tractor will evaluate the } \\
\text { monitoring results and determine } \\
\text { if environmental standards are } \\
\text { being met and will inform DOE } \\
\text { in the event of non-compliance. } \\
\text { "The plan will be conducted for } \\
1 \text { year, with a plan for a } \\
\text { 2nd year to be developed. } \\
\text { The contractor shall pro- } \\
\text { vide DOE quarterly status } \\
\text { reports and an annual } \\
\text { report.". }\end{array}$ & $\mathrm{C}, \mathrm{O}$ & $\begin{array}{l}\text { Air quality, NF; } \\
\text { remainder, F. }\end{array}$ & $\begin{array}{l}\text { Data should be } \\
\text { compared with } \\
\text { appropriate } \\
\text { criteria. } \\
\text { None }\end{array}$ \\
\hline
\end{tabular}

${ }^{a}$ Reference documents: Environmental Assessment [EA (DOE, 1981)], finding of no significant impact (FONSI) dated March 16, 1981.

${ }^{b}$ Directly quoted from the reference document.

${ }^{b}$ Directly quoted from the reference document.

${ }^{c} \mathrm{C}=$ construction; $\mathrm{D}=$ decommissioning; $\mathbf{0}=$ operation; $\mathrm{PC}=$ preconstruction.

${ }^{d}$ As determined by onsite inspection, August 12,$1982 ; \mathrm{F}=$ fulfilled; $\mathrm{NF}=$ not fulfilled; $\mathrm{NV}=$ not verifiable. 
The pit used to collect spills from the drill site is also not lined with a synthetic liner. However, this pit is pumped soon after receiving any spilled materials (Berning, 1982b).

- Storms-The scheduling of project activities to avoid potential problems associated with major storms is a goal that can conflict with project completion goals and funding constraints. During the August site visit, the construction rig for replacing the well casing was in place during the hurricane season. However, in the event of the threat of tropical storms, it is standard practice to remove any hazardous materials and portable equipment. If large drill rigs cannot be removed from the site, they are secured by lowering the derrick to a horizontal position (Berning, 1982b).

\subsubsection{Monitoring Activities}

This section reviews the adequacy of air, noise, water, ecological, and geological monitoring activities at the Gladys McCall well site. It also makes recommendations for further monitoring where deemed necessary. LSU conducted all environmental monitoring at the Gladys McCall site, either directly or through the use of subcontractors.

\subsubsection{Air quality}

Although the EA for the Gladys McCall well (DOE, 1981) stated that the Louisiana Geological Survey would monitor air quality around the well site, no air quality monitoring was performed (Van Sickle, 1982a). The objectives of the air quality monitoring program for the Gladys McCall well (DOE, 1981) were identical to those stated for the Dow well (Sect. 3.1.2.1). Air sampling and analysis were to have been from a fixed automated monitoring unit located about $3.2 \mathrm{~km}(2 \mathrm{mi})$ north of the test well site. The location of the monitor was determined using procedures consistent with techniques recommended by the EPA (1980). Continuous measurements of $\mathrm{SO}_{2}, \mathrm{H}_{2} \mathrm{~S}$, THC, and methane were to have been made. Meteorological data monitored were to have included wind speed, wind direction, temperature, and precipitation.

The monitoring plan identified the appropriate pollutants to monitor, based on typical natural gas analyses of the Louisiana geopressured zone (Goldsberry, 1980). Additional monitoring of the ambient air in the immediate vicinity of the flare would have provided data on substances potentially derived from the geopressure brine (see the second objective, Sect. 3.1.2.1). The appropriate meteorological parameters were selected to evaluate pollutant behavior in the atmosphere. The EPA reference methods (40 CFR Parts 50 and 53) were to be used in monitoring the pollutants, and EPA guidelines were to be followed when monitoring meteorological parameters (EPA, 1980).

The lack of air quality degradation expected from the project, combined with the fact that air monitoring programs at the Dow and Sweet Lake well sites detected few, if any, changes in air quality that could be attributed to well activity, contributed to the decision not to monitor air quality at the Gladys McCall site. Funding cutbacks in FY 1982 were responsible for reductions in environmental monitoring at all the geopressure wells and thus 
made it less likely that air quality monitoring would begin at Gladys McCall. Implementing a monitoring program at this late date in the development of the well would be of marginal value because limited air quality baseline data are available for the site, making a comparison of ambient concentrations difficult.

\subsubsection{Noise}

No noise monitoring was conducted at the Gladys McCall well site (Van Sickle, 1982c). Initiation of noise monitoring would provide little useful information on the noise impacts of the project because the noisiest phase of the project, well drilling, has been completed. Currently, the principal noise source at the well is the diesel generator. The generator is located on the side of the site that is away from the nearest residences to minimize possible disturbance.

Noise levels generated during flow testing are likely to be similar to those observed during the site visit; thus, noise monitoring at the Gladys McCall site for the duration of the project is not recommended because no significant noise impacts are expected. If noise monitoring were to have been done for this project, it should have occurred during well drilling. Noise simulation modeling done for the EA found that noise levels generated during well drilling decayed to ambient levels before reaching the nearest sensitive receptor (DOE, 1981).

\subsubsection{Water quality}

Monitoring of surface water and groundwater quality was initiated at the Gladys McCall site in May and June 1981. At present, sampling is continuing on a monthly basis. Three surface-sampling stations were selected, and two wells for observation of groundwater. were drilled (Fig. 4). The sampling to date has indicated seasonal variation and trends in water quality but no alteration of water quality that can be attributed to the test well (Bebout et al., 1982).

In evaluating the water quality monitoring, consideration was given to the adequacy of (1) sampling locations, (2) frequency of monitoring, (3) choice of water quality constituents to be monitored, and (4) presentation and interpretation of results. The monitoring program for the Gladys McCall test well site appears capable of revealing any significant changes in water quality resulting from well operations. Several aspects of the program which could be clarified are as follows: (1) the results of sampling should be discussed and interpreted by comparison with appropriate water quality criteria (e.g., "Water Quality Criteria for Toxic Substances," 45 FR 79318-79) and by comparison with concentrations typical for the region; and (2) the reporting of monitoring data should include information (or indicate references where information can be found) on analytical methods used, the laboratory performing the analyses, and the limits of detection.

\subsubsection{Ecology}

Ecological parameters were used in a study of shoreline disappearance and marsh loss in the vicinity of the Gladys McCall well site before the commencement of testing. Beyond 
ORNL-DWG 83-8430

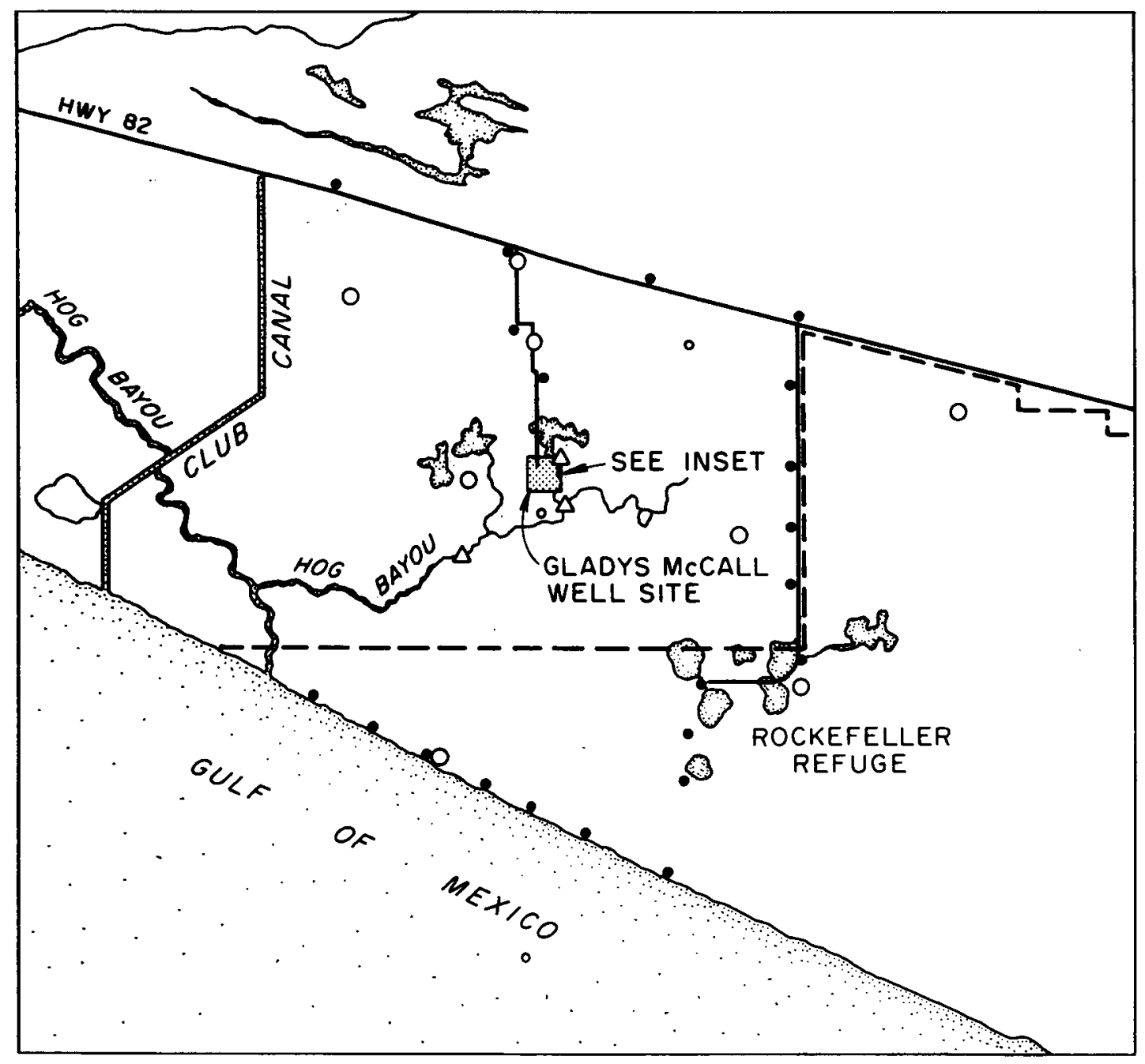

$\triangle$ SURFACE WATER SAMPLING STATION

O SEISMOMETER

- WELL

- BENCHMARK
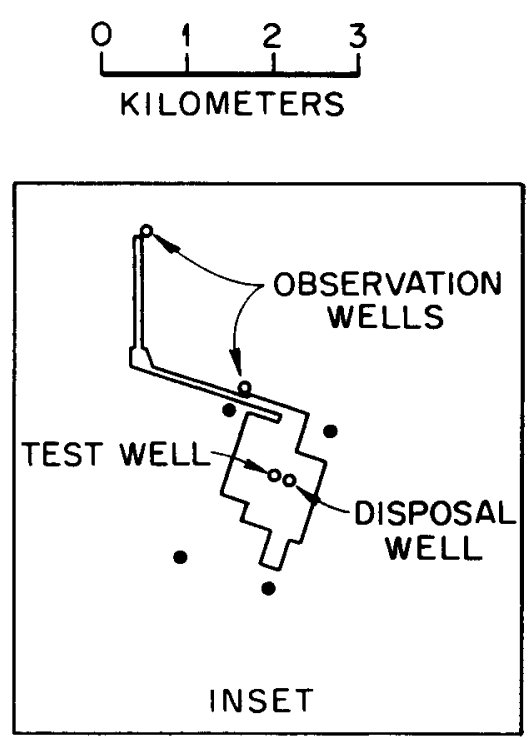

Fig. 4. Locations of field environmental monitoring stations near the Gladys McCall geopressure design well. Source: Bebout et al. (1982), Fig. 1. 
this and a baseline characterization of the site and surroundings, no ecological monitoring has been conducted at the Gladys McCall site, and no such monitoring is recommended at this time. However, because of the ecological importance of the area and the proximity of the Rockefeller Wildlife Refuge, monitoring could become necessary if (1) results of water quality monitoring (Sect. 3.3.2.3) suggest changes due to geopressure activity which might damage marsh life or (2) a blowout or other large spill should occur.

\subsubsection{Subsidence and microseismicity}

Subsidence and microseismic activity have been monitored at the Gladys McCall site using the methods described in Sect. 3.2.2.5. As with the other two wells in Louisiana, current plans are (1) not to conduct the survey work unless or until the wells are tested and (2) to continue microseismic and leveling work for one year after DOE has completed operations (Van Sickle, 1982c).

\subsubsection{Decommissioning}

Future use or decommissioning of the Gladys McCall site is uncertain and partially dependent on the test results obtained from the well. DOE's schedule for the project calls for 12 months of well operation, flow testing, and associated research at the site after successful completion of the well. This-would be followed by complete site decommissioning, with wells plugged and abandoned. Flow testing occurred between March and May 1983.

Well operation may indicate that the geopressured reservoir can be utilized economically. If natural gas production is sufficient and gas quality is high, a connection may be made with the nearest gas pipeline. Geothermal energy may also find application in agricultural drying, electrical generation, or other uses. The choices between further site development, mothballing, and site decommissioning will depend on many factors which are currently uncertain. Future environmental impacts are difficult to predict, as are the monitoring and mitigation efforts that will be appropriate.

Because the future use of the Gladys McCall site is uncertain and will remain uncertain for perhaps a year or more, recommendations regarding decommissioning are premature at this time. If a decision is made to abandon the site, the planning for decommissioning should proceed based on DOE's previous commitments, the legal requirements of the state of Louisiana, the site's condition, and any other relevant factors. DOE may be able to accommodate the wishes of the site's landowner, but considering that adjacent land is wetland, including the Rockefeller Refuge, highest priority should be given to restoring the site to an undisturbed condition to the extent possible. Because spent drilling muds are currently stored in the reserve pit at the site, a site inspection and additional monitoring may be appropriate in conjunction with decommissioning. 


\subsection{Pleasant Bayou}

The Pleasant Bayou geopressure test well project was undertaken by DOE and the University of Texas, Center for Energy Studies, to evaluate the geopressure potential of the area. Tests to be conducted included flow rates, fluid composition, temperature, gas content, geologic characteristics, and the potential for subsidence due to subsequent fluid production (DOE, 1978).

As a result of drilling problems with the first well at the site, Pleasant Bayou No. 1, a replacement well, Pleasant Bayou No. 2, was spudded on January 25, 1979 (DOE, 1979a). This second well was drilled to 5,000 $\mathrm{m}(16,500 \mathrm{ft})(\mathrm{DOE}, 1979 \mathrm{~b})$. Phase I production tests (short-term) were completed prior to June 1980 (C. K. Geoenergy, 1980). A series of problems with surface facilities and with the production string ensued. The well was reworked to retrieve a portion of production string lost downhole (C. K. Geoenergy, 1982a; Blumhardt, 1982), and on August 23, 1982, long-range flow testing began. On September 6, 1982 , the flow rate was $3,148 \mathrm{~m}^{3}(19,800 \mathrm{bbl})$ of brine per day, with production of $11,750 \mathrm{~m}^{3}\left(415,000 \mathrm{ft}^{3}\right)$ of gas. Flowing well temperature was $137^{\circ} \mathrm{C}\left(279^{\circ} \mathrm{F}\right)$ (C. $\mathrm{K}$. Geoenergy, 1982b). Production at this rate continued until April 1983, when scale buildup required that the well be shut-in (C. K. Geoenergy, June 1983b). As of August 1983, the well was being reworked to remove the 0.13-m (5-in.) tubing (DOE, 1983).

\subsubsection{Commitment Checklist}

The environmental mitigation and monitoring commitments for the Pleasant Bayou wells are presented in Table 4. The status of these commitments was verified by onsite inspection on August 13,1982. Comments on these commitments are as follows:

- Site drainage-The site is partly surrounded by the remnants of a former ring levee, and portions of the completed pad for well No. 2 drain offsite rather than into pits. As a result, some rainwater from the site drains offsite. Because of the cleanliness and otherwise effective construction of the site, such drainage does not constitute a problem. Erosion losses have been adequately mitigated because the pad is graveled and peripheral areas have been seeded. Similarly, the pad for well No. 1 has been leveled, access and work areas graveled, and the perimeter seeded.

- Mud and reserve pits-The mud and reserve pits have not yet been filled, and hence no reinjection of liquid wastes has occurred. We recommend that DOE ensure, before its involvement ends, that liquid wastes are reinjected or hauled to an approved disposal site and that solid residues are buried in the pits or hauled to an approved disposal site. The method chosen will depend on whether the pits remain in use as a part of further commercial development.

- Disposal station-The disposal station was not housed because electric pumps proved unnecessary for reinjection of brines.

- Decommissioning-All unneeded areas of the site should be graded, covered with soil, and seeded. As noted in Table 4, it would be permissible to include nonnative, adapted 
Table 4. Mitigation and monitoring commitment checklist for the Pleasant Bayou geopresesure deeign well, Brasoria County, Texas

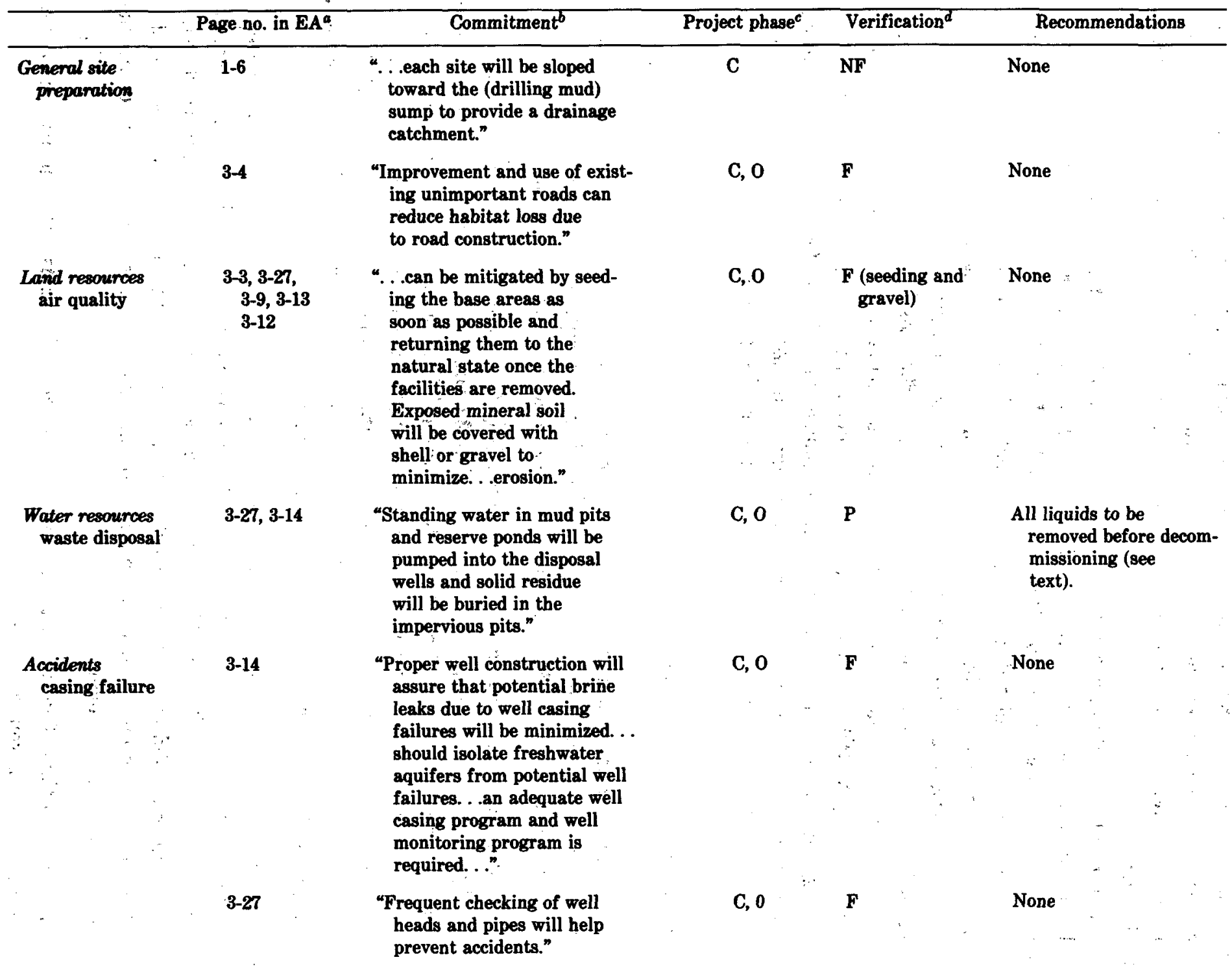


Table 4. (Continued)

\begin{tabular}{|c|c|c|c|c|c|}
\hline & Page no. in $\mathbf{E A}^{a}$ & Commitment $^{b}$ & Project phase $^{c}$ & Verification $^{d}$ & Recommendations \\
\hline safety & $1-12$ & $\begin{array}{l}\text { The disposal station will be } \\
\text { housed to protect it from } \\
\text { weather since the pumps are } \\
\text { electrically driven and have } \\
\text { a high horsepower rating." }\end{array}$ & $\mathrm{C}, \mathrm{O}$ & NF (see text) & None \\
\hline Decommissioning & $1-18$ & $\begin{array}{l}\text { "Abandoned wells will be } \\
\text { plugged with cement or welded } \\
\text { shut below ground level and } \\
\text { will be in compliance with } \\
\text { appropriate state rules and } \\
\text { regulations. . the disturbed } \\
\text { area will be backfilled and } \\
\text { replanted with species native } \\
\text { to the areas. Mud pits will } \\
\text { be drained of free water and } \\
\text { thus water will be pumped into } \\
\text { the disposal well prior to its } \\
\text { abandonment. Residue will be } \\
\text { buried in the impervious pits." }\end{array}$ & $\mathbf{D}$ & NV, P & $\begin{array}{l}\text { Nonnative } \\
\text { species may be } \\
\text { accepted (see } \\
\text { text). }\end{array}$ \\
\hline
\end{tabular}

EA =- Environmental Assessment (DOE 1978). Other references: memos to file dated March 23, 1978; January 15, 1979; and February 8, 1979. birectly quoted from the EA (DOE 1978).

${ }^{C} \mathrm{C}=$ construction; $\mathrm{D}=$ decommission; $\mathrm{O}=$ operation.

${ }^{d}$ As determined by onsite inspection, August 13,$1982 ; F=$ fulfilled, NF $=$ not fulfilled, $P=$ pending, $N V=$ not verifiable. 
plant species in the seeding mixture if such species have proven suitable for stabilization in the area. Advice on species to use can be obtained from the county Soil Conservation Service officer.

- Flooding-It is not clear whether Executive Order No. 11988, "Floodplain Management," has been complied with. Although the possibility of flooding is not covered in the commitments, DOE should recognize that the site is both within the 100-year floodplain and subject to flooding from a major hurricane. The area has been flooded ten times since 1939, including the flooding by Hurricane Carla in 1961 (DOE, 1978). During August 1983, Hurricane Alicia brought heavy rains, high winds, and flooding to south Texas after coming aground near Galveston. Fortunately, the eye of the hurricane passed directly over the Pleasant Bayou site, sparing it from damage (Goldsberry, 1983). An increase in the volume of the mud pit was noted, but no liquid wastes were released to the environment (Goldsberry, 1983). It is possible that flooding in the future could result in damage to equipment and washing of stored liquid wastes to the surrounding areas. For this reason, it is recommended that the contents of the mud pit be disposed of or removed from the site rather than remain for an extended period.

\subsubsection{Monitoring Activities}

In this section the adequacy of air and water quality, noise, ecological, and geological monitoring is reviewed, and recommendations for further monitoring are made. The Bureau of Economic Geology, University of Texas at Austin, conducted the environmental monitoring at the Pleasant Bayoü site.

\subsubsection{Air quality}

An air quality monitoring program was conducted in the vicinity of the Pleasant Bayou well site by Radian Corporation under subcontract to the Bureau of Economic Geology, University of Texas. Data were collected from February 1978 through December 1980 by a fixed, continuous monitor located approximately $0.8 \mathrm{~km}(0.5 \mathrm{mi})$ northwest of the test well (Fig. 5). The station was selected using procedures consistent with EPA guidelines (EPA, 1980).

The goal of the air quality monitoring program was to determine baseline air quality at the Pleasant Bayou well site (Gustav̌son, 1982). Ambient levels of the following pollutants were monitored: $\mathrm{SO}_{2}$, particulates, methane, and $\mathrm{H}_{2} \mathrm{~S}$. All automated instrumentation was consistent with EPA-approved techniques (40 CFR Parts 50 and 53). Instrument calibration, data reduction, and quality assurance were also completed in a manner consistent with EPA guidelines (EPA, 1980).

The greatest potential for air pollution during geopressure development occurs when the natural gas is separated from the brine and then cleaned and sold to a pipeline or flared (Goldsberry, 1980). Typically, the gas treatment consists of dehydration and removal of $\mathrm{H}_{2} \mathrm{~S}$ and $\mathrm{CO}_{2}$. The $\mathrm{H}_{2} \mathrm{~S}$ is usually incinerated and then released to ambient air as $\mathrm{SO}_{2}$. Thus, the principal air quality impact associated with gas treatment is the release of small amounts of 


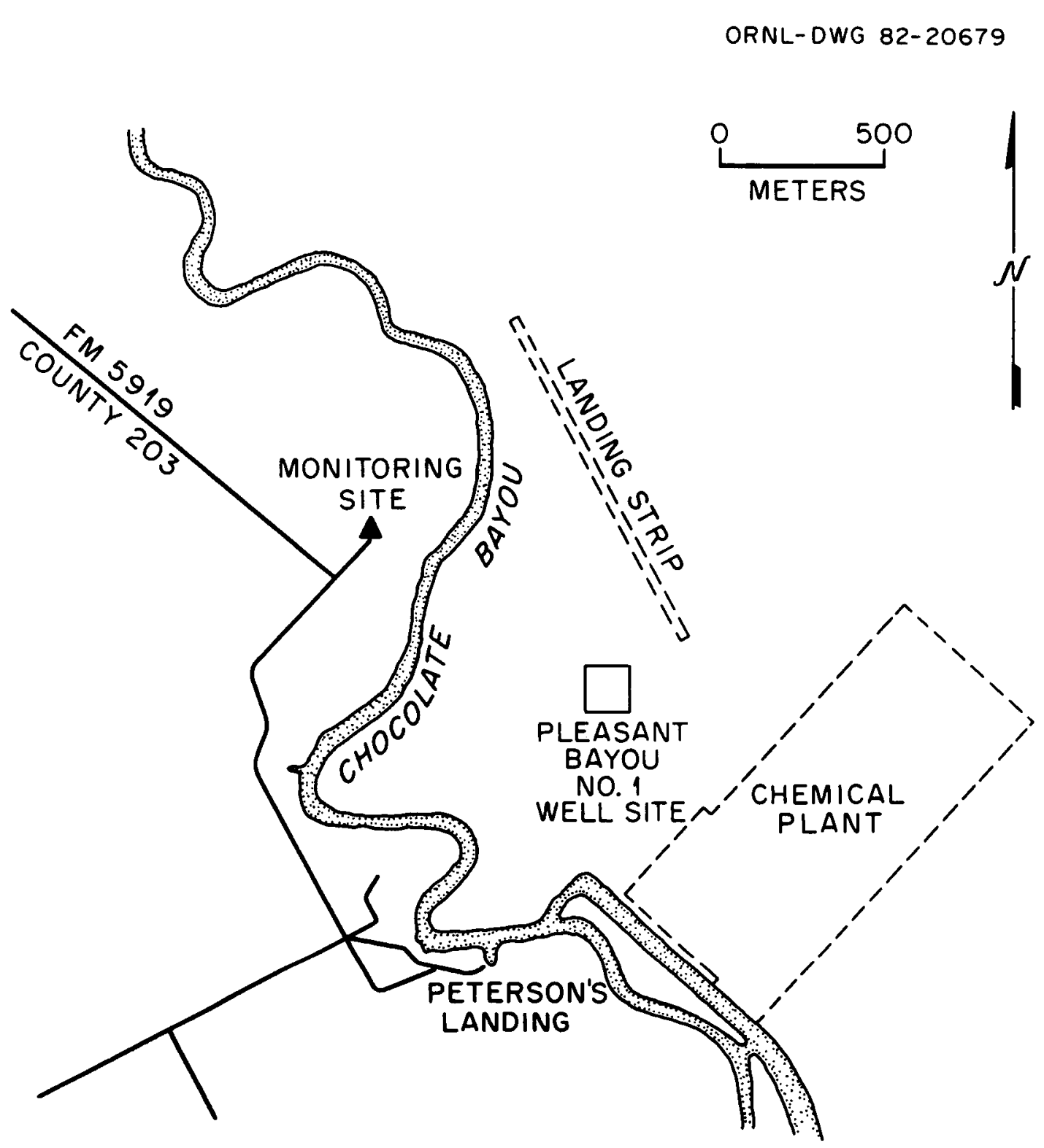

Fig. 5. Location of air quality monitorins station near the Pleasant Bayou geopressure design well. Source: Gustavson, Howard, and McGookey (1980), Fig. II. 
$\mathrm{SO}_{2}$. The pollutants selected for analysis are typical of those found in gases in geopressure reservoirs along the Texas-Louisiana Gulf Coast (Goldsberry, 1980).

The results of the baseline air monitoring program suggest that major air pollution sources to the northwest, north, east, and southeast of the well site contribute to pollution at the site; these directions coincide with the locations of major petrochemical and industrial complexes in Houston, Galveston, and Texas City. Nearby petrochemical plants undoubtedly affect air quality at the site when the wind is from the east; however, the composition of emissions from nearby industry (e.g., the Monsanto plant) is not known, so the contribution of neighboring industry to air quality at the well site is difficult to determine (Gustavson, 1982). NAAQS for particulates and $\mathrm{SO}_{2}$ were not exceeded at the well site during 1980, which was a period that included the Phase I flow testing of the well.

Meteorological monitoring was begun at the site in January 1979. Wind speed and wind direction data were monitored; these two parameters are adequate data for evaluating the dispersion characteristics of the atmosphere in the vicinity of the site. Since only limited information is available on the meteorological monitoring, it is impossible to determine if the monitoring was done using procedures consistent with EPA guidelines (EPA, 1980).

In general, the air quality monitoring was adequate. Additional data analysis should be done at the end of the project to characterize air quality during each phase of geopressure development at the site: preconstruction (baseline), construction, well drilling, and flow testing. None of the available environmental monitoring reports for the Pleasant Bayou well site (Gustavson, 1979 and 1982; Gustavson, Howard, and McGookey, 1980) identify or summarize air quality during each of these time periods. The data records should be examined to determine if there is any statistically significant change in air quality associated with well activity (construction, drilling, etc.). These additional analyses will provide a more complete picture of the air quality impacts of geopressure development at Pleasant Bayou.

\subsubsection{Noise}

The Bureau of Economic Geology, University of Texas, contracted Radian Corporation to conduct a baseline noise survey for the well site and to predict the impacts of geopressure development on the background noise levels.

Radian conducted a baseline field noise survey in January 1978 prior to the beginning of well drilling. The survey consisted of measuring ambient noise levels on the decibel Aweighted scale every 460 to $600 \cdot \mathrm{m}(1500$ to $2000 \mathrm{ft})$. within the residential area surrounding the proposed site. Noise measurements were also taken every $330 \mathrm{~m} \mathrm{(1000} \mathrm{ft)}$ parallel to the road leading to the Monsanto chemical plant. All field measurements were made in accordance with ANSI S1.13-1971, "Methods for the Measurement of Sound Pressure Levels."

Standard nonacoustical information, such as wind speed and humidity, was also noted, along with observed extraneous influences. Calibration of the instrumentation was performed prior to, during, and subsequent to each sample exercise. All instrumentation satisfies specifications for sound level meters (Gustavson, 1979). 
The baseline noise survey indicated that existing day-night noise levels $\left(L_{d n}\right)$ in the Peterson's Landing area were between 40 and $50 \mathrm{dBA}$ (Gustavson, 1979). The survey data showed a definite influence of noise from the Monsanto chemical plant; variations in the observed 24-h sound pressure levels were attributed to production changes, steam blowoff, and low-frequency flare noise at the Monsanto plant (Gustavson, 1979). The baseline noise survey adequately characterized the sound field present at the well prior to development of the geopressure resource.

To predict the noise impacts of geopressure development on the existing sound field, Radian measured sound levels from an operating drill rig of the same type that was planned for use at the Pleasant Bayou site. Next, mathematical techniques were used to simulate the attenuation of the drill rig noise with distance. The predicted sound levels from drilling operations were added to the baseline sound levels to produce a total sound level, which was then compared with criteria to determine if a significant impact would occur, whether mitigation measures would be needed, and how effective they would be in reducing the magnitude of the impact.

During January 1978, sound pressure levels were measured at various distances from a 2100-HP drill rig operating at Hallettsville, Texas. These sound levels were then used as input to a noise level prediction model that describes the frequency and directional capabilities of noise from the source and then calculates the attenuation of noise from the source to the concerned area. The model takes into account geometric spreading, molecular adsorption, and vegetation attenuation. The output from the model provides the total sound pressure spectrum at any point within the impact area. The modeling results showed that the noise field produced by the drilling rig is asymmetrical (Fig. 6). By locating the rig so that the major lobes of the noise field are directed away from nearby inhabited areas (Peterson's Landing), the noise generated by the drilling rig would have no appreciable environmental effect on the Peterson's Landing community and on residents along the concerned portion of the Chocolate Bayou (Gustavson, 1979). The modeling results indicated a predicted noise level of about 40 to $50 \mathrm{dBA}$ in the Peterson's Landing area, which is within the guidelines for health and welfare established by the EPA (EPA, 1974) and is equivalent to the baseline noise levels at the Peterson's Landing area.

In August 1978, another field noise survey was conducted by Radian to measure ambient noise levels during operation of the drill rig and to ensure that the orientation of the rig had achieved its purpose of mitigating noise impacts from well drilling. At that time it was learned that the drilling contractor had decided to use a 4800-HP drilling system instead of the 2100-HP system originally planned. The more powerful system was actually 15 to $20 \%$ quieter because of soundproof engine enclosures. The field survey conducted during drilling agreed with the modeling results by showing that noise from the drilling rig was masked by noise from the Monsanto plant and that implementation of mitigation measures (i.e., proper rig orientation) achieved the desired result.

\subsubsection{Water quality}

Monitoring of surface water and groundwater quality was initiated at the Pleasant Bayou site in March 1978, and regular monthly sampling of both surface water and 
ORNL-DWG 82-20678

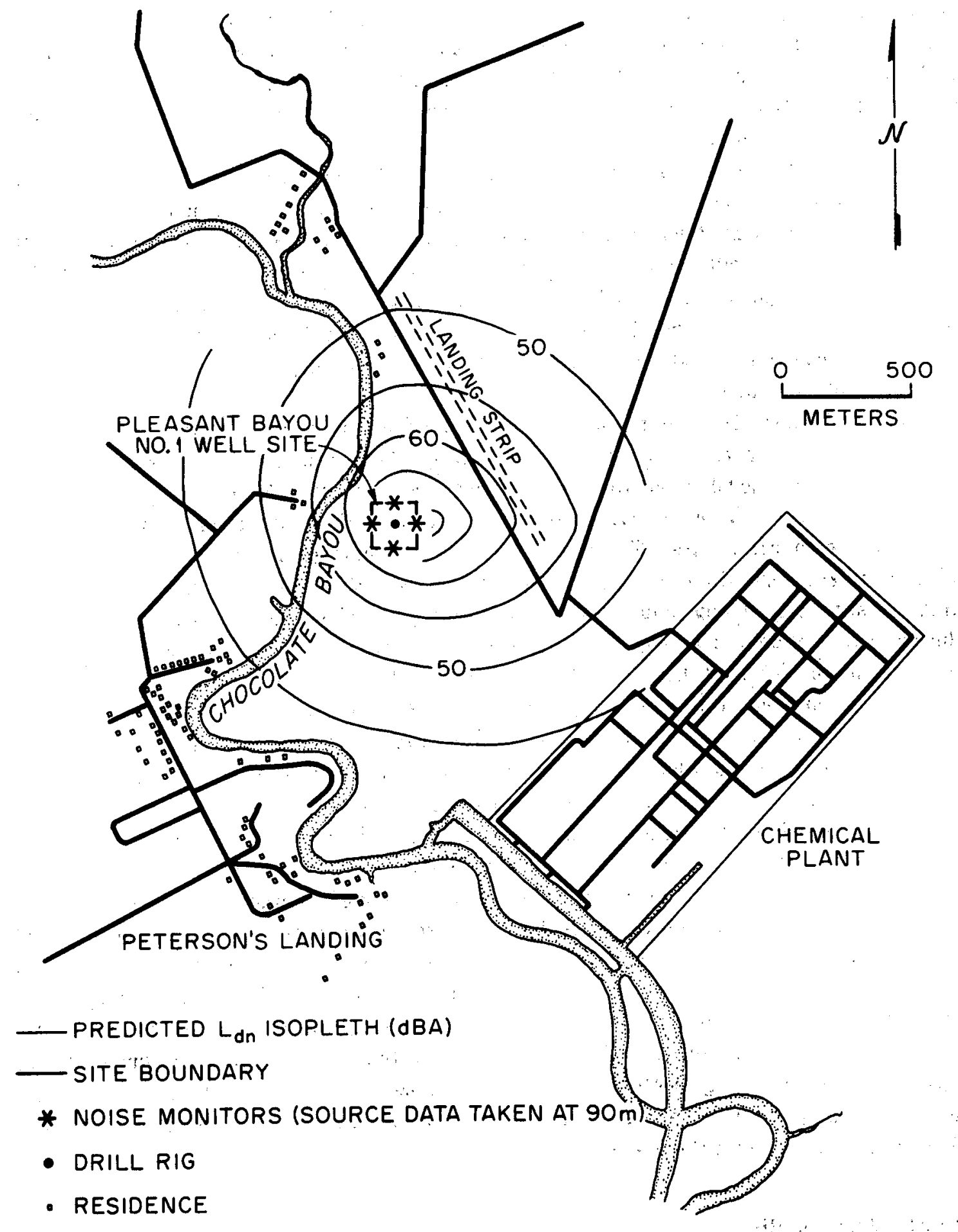

Fis. 6. Predicted sound levels from well drilling near the Pleasant Bayou geopressure design well. Source: Gustavson (1979, vol. IV), Fig. 10. 
groundwater began in November 1978. Sampling continued on a monthly basis until February 1982. The waters of Chocolate Bayou are sampled both upstream and downstream of the test well site, and samples are taken at the water's surface and near the bottom. Groundwater is sampled at three wells, the locations of which are indicated in Fig. 7. Monitoring reports have indicated that the surface water chemistry of Chocolate Bayou is highly variable because of mixing of fresh water with nearby marine waters. Monitoring of shallow groundwater near the test well site has indicated only minor influences from mixing with salt water. The sampling indicated considerable variation in water quality but no alteration that could be attributed to the test well (Gustavson, 1979 and 1982; Gustavson, Howard, and McGookey, 1980).

In evaluating the water quality monitoring, consideration was given to the adequacy of (1) sampling locations, (2) frequency of monitoring, (3) choice of water quality constituents being monitored, and (4) presentation and interpretation of results. The monitoring program for the Pleasant Bayou site appears capable of revealing any significant changes in water quality resulting from well operations. Several aspects of the program which need clarification are as follows: (1) a figure indicating the location of surface water monitoring stations should be provided; (2) the rationale for choice of sampling locations should be discussed (i.e., Are any of the sampling stations or wells intended to serve as control stations?); (3) the results of sampling should be discussed and interpreted by comparison with appropriate water quality criteria (e.g., "Water Quality Criteria for Toxic Substances," 45 FR 79318-79) and by comparison with concentrations typical for the region; and (4) the reporting of monitoring data should include information on the limits of detection (or indicate references where this information can be found).

\subsubsection{Ecology}

Baseline information on the ecology of the area was developed from field reconnaissance and existing literature; no further monitoring is needed except in the event of a blowout. In such an event, a program should be developed to monitor impacts to terrestrial and aquatic biota. Such a program would include air and water quality monitoring, sampling of potentially affected population, and measurement of soil properties on affected and adjacent unaffected areas. The information from such studies would be useful in documenting the nature and extent of ecological damage, in making decisions regarding cleanup, and in predicting the impacts of future geopressure development.

\subsubsection{Subsidence and microseismicity}

An initial leveling survey was conducted by Teledyne Geotronics and can be repeated to detect subsidence following production tests (Gustavson, Howard, and McGookey, 1980). A multiliquid tiltmeter was operated periodically during 1980 at the test well site but gave no evidence of subsidence (Gustavson, Howard, and McGookey, 1982). Before subsequent surveys are made, the final amount of reservoir pressure drawdown should be checked against current subsidence models to predict whether detectable subsidence is likely. Recent models suggest that a drawdown of $21 \mathrm{MPa}$ (3000 psi) could produce a change ranging between $0.2 \mathrm{~cm}(0.1 \mathrm{in}$.) (DOE, 1981) and $12.5 \mathrm{~cm}$ (5 in.) (DOE, 1982). Although such 


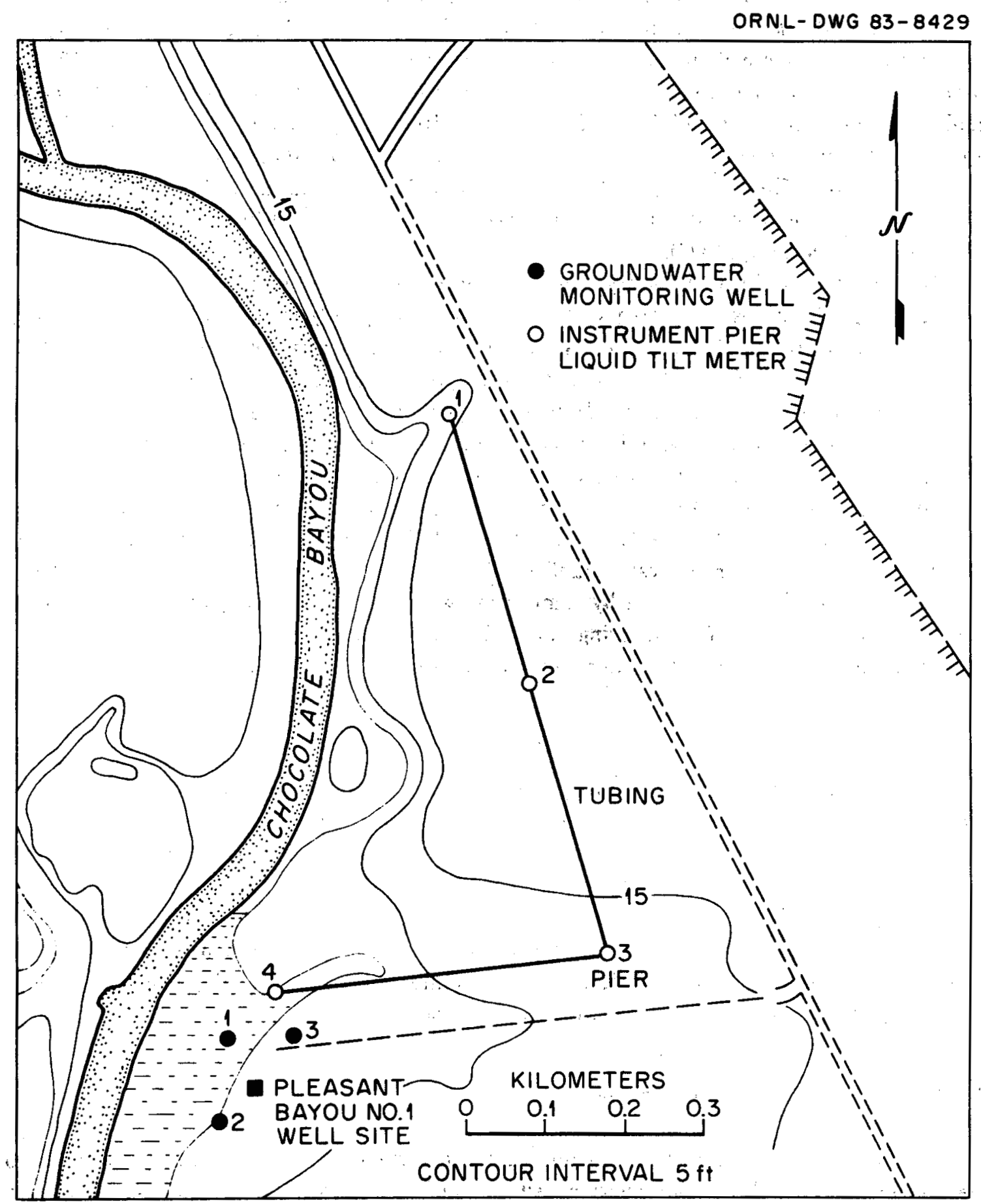

Fig. 7. Locations of groundwater monitoring stations near the Pleasant Bayou geopreasure design well. Source: Gustavson (1979, vol. I), Fig. 2. 


$$
49 / 50
$$

changes would be minor in comparison to other causes (Cotter, 1982), subsidence of more than $0.3 \mathrm{~m}$ has occurred in the Chocolate Bayou field north of the test well where gas has been produced from a shallower portion of the geopressured reservoir (Gustavson and Kreitler, 1976). Because many factors contribute to the uncertainty of subsidence predictions, monitoring should be continued in order to improve our understanding of the role of fluid withdrawal in causing subsidence (Dorfman and Harkins, 1982). Microseismic activity near the Pleasant Bayou well site has been monitored with one surface instrument and four instruments in $30-\mathrm{m}$ (100-ft) boreholes. This array has detected events with a magnitude of 0.5 , including microseismic events believed to be associated with brine injection to the Pleasant Bayou disposal well (Gustavson, Howard, and McGookey, 1982). Microseismic monitoring is continuing and should continue, if possible, at least until the completion of production testing.

\subsubsection{Decommissioning}

Future use of the Pleasant Bayou site for geopressure development depends on the results of continued flow tests. Currently, DOE plans to test the well until September 30, 1983. Future commercial activity is, however, possible following testing. Gas sales might be used by DOE to partially recover its costs (Lombard, 1982a). Cleanup of the gas is straightforward, and connection to a pipeline presents no major problems. Additional commercial ventures, including heat for various aquacultural applications, appear feasible. It appears possible that the site will remain active in some form following termination of DOE's involvement. 


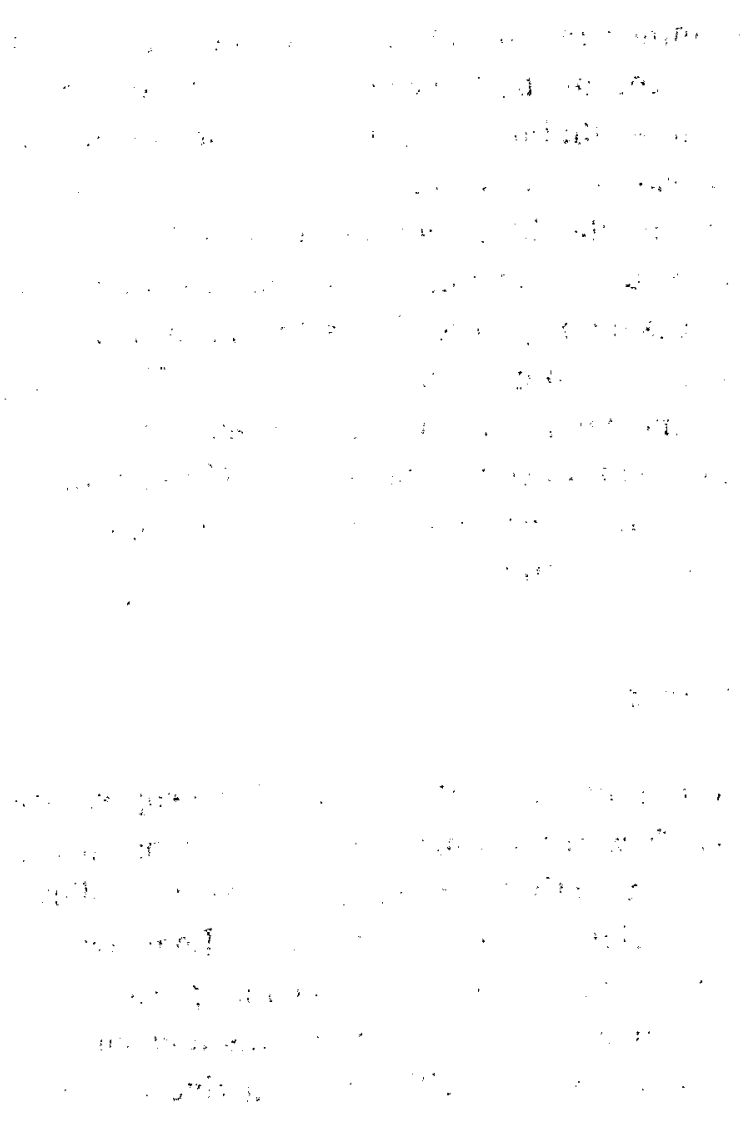




\section{CONCLUSIONS AND RECOMMENDATIONS}

The DOE and its operating contractors at the four geothermal design well sites adequately implemented most of the mitigation measures and monitoring recommended in the project EAs. Because of the effectiveness of these measures and because of the generally benign nature of geothermal energy resource development and utilization, the environmental impacts of the DOE design well program have been minimal.

The most significant potential environmental impacts from geopressure projects are surface water, groundwater, and soil contamination and subsequent ecological damage. The most probable causes of such impacts are (1) careless or improper handling and storage of materials, wastes, and fluids associated with well drilling and (2) accidents. As an example, the brine pit at the Dow site developed a leak, providing a potential pathway for toxic substances to enter the environment. At Pleasant Bayou, the lack of a ring levee around the site affords the opportunity for heavy rainfall to flush spent drilling fluids from a storage pit into the environment.

As a result of this study, the torn liner at the Dow well was repaired, and the soil under the liner was removed for appropriate disposal upon decommissioning (Storm, 1983), and the stored fluids at the Pleasant Bayou well will either be removed or the ring levee repaired (Lombard, 1982b).

The monitoring activities outlined in the EAs were not carried out as explicitly as stated, primarily because (1) monitoring during initial testing at the Pleasant Bayou and Sweet Lake sites indicated little or no change in baseline concentrations or ambient levels of the parameters monitored and (2) federal funding cutbacks have resulted in the termination of some monitoring and the failure to initiate that which had been planned. A review of the monitoring data collected to date suggests that no adverse impacts related to well activity have occurred at or near the well sites.

This evaluation of environmental monitoring and mitigation measures at the geopressure design wells was a logical extension of the NEPA-related activities associated with these projects which provided a broader view of the environmental impacts of the technology. Furthermore, this study has illustrated that NEPA documents (in this case, EAs) can serve as action plans for characterizing environmental impacts and need not be confined to only paper exercises.

It is recommended that environmental monitoring and mitigation activities be evaluated for other projects which have undergone the NEPA environmental review process and which have achieved fruition, particularly projects of a less environmentally benign nature (e.g., coal-fired plants, nuclear power plants, etc.) for which EISs have been prepared. A computer search of EISs prepared to date could be used to identify such projects so that follow-up site visits may be conducted to evaluate the impacts predicted and measures recommended in the 
NEPA documents. Such an evaluation would be especially useful in areas for which noncompliance monitoring (not related to permits, such as socioeconomics and ecology) is recommended. 


\section{REFERENCES}

Bebout, D. G., A. Bassioum, D. R. Carver, C. G. Groat, R. H. Pilger, Jr., and F. M. Wrighton. 1982. Technical Support for Geopressured-Geothermal Well Activities in Lonisiana, Annual Report, Nov. 1, 1980-Oct. 31, 1981. DOE/NV/10174. Prepared by the Louisiana Geological Survey for the U.S. Department of Energy, March.

Berning, J. 1982a. Site Manager, Sweet Lake Geopressure Design Well. Personal communication with D. B. Hunsaker, Jr., Oak Ridge National Laboratory, September 1.

Berning, J. 1982b. Site Manager, Gladys McCall Geopressure Design Well. Personal communication with R. D. Roop, Oak Ridge National Laboratory, August 12.

Blumhardt, H. 1982. Site Manager, Pleasant Bayou Geopressure Design Well. Personal communication with J. W. Webb, Oak Ridge National Laboratory, August 13.

C. K. Geoenergy Corp. 1980. DOE/Industry Geopressured-Geothermal Energy Forum Newsletter. C. K. Geoenergy Corp., Las Vegas. June.

C. K. Geoenergy Corp. 1981a. DOE/Industry Geopressured Geothermal Energy Forum Newsletter. C. K. Geoenergy Corp., Las Vegas. February.

C. K. Geoenergy Corp. 1981b. DOE/Industry Geopressured Geothermal Resource Development Program. Executive Summary of Drilling and Testing Subgroup and Overview Forum Meetings. June 16, 1981, New Orleans. Prepared for U.S. Department of Energy, Division of Geothermal Energy.

C. K. Geoenergy Corp. 1982a. DOE/Industry Geopressured Geothermal Energy Forum Quarterly Newsletter. C. K. Geoenergy Corp., Las Vegas, June.

C. K. Geoenergy Corp. 1982b. DOE/Industry Geopressured Geothermal Energy Forum Quarterly Newsletter. C. K. Geoenergy Corp., Las Vegas, September.

C. K. Geoenergy Corp. 1983a. DOE/Industry Geopressured Geothermal Energy Forum Quarterly Newsletter. C. K. Geoenergy Corp., Las Vegas, March.

C. K. Geoenergy Corp. 1983b. DOE/Industry Geopressured Geothermal Energy Forum Quarterly Newsletter. C. K. Geoenergy Corp., Las Vegas, June.

Clusen, R. C. 1980a. Determination for the Dow Parcperdue Geopressure Project, Vermilion Parish, Louisiana. Memorandum for Ruth M. Davis, Assistant Secretary for Resource Applications Regarding the National Environmental Policy Act (NEPA). U.S. Department of Energy, Washington, D.C., May 9. 
Clusen, R. C. 1980b. Finding of No Significant Impact for the DOE Sweet Lake No. 1 Geopressure Project, Cameron Parish, Louisiana Memorandum for Ruth M. Davis, Assistant Secretary for Resource Applications Regarding the National Environmental Policy Act (NEPA). U.S. Department of Energy, Washington, D.C., March 11.

Cotter, J. B. 1979. Engineering and Energy Applications Division, U.S. Department of Energy, Nevada Operations Office. Memorandum to Bennie G. DiBona, Acting Director, Division of Geothermal Energy, U.S. Department of Energy.

Cotter, J. B. 1982. Director, Energy Applications Division, U:S Department of Energy, Nevada Operations Office. Review comments on draft report; Evaluation of Environmental Mitigation and Monitoring Commitments at Four Geopressure Design Wells. Letter to A. W. Reed, Oak Ridge National Laboratory, October 13.

Dames and Moore, Inc. 1982. Analysis of Hydrologic and Envirommiental Effects of Drilling Mud Pits and Prodiced Water Impoundments. Prepared for the American Petroleum Institute, Dallas, Tex.

Dorfman, M. H., and H. B. Harkins, Jr. 1982. University of Texas at Aútin, Department of Petroleum Engineering. Letter to A. W. Reed, Oak Ridge National Laboratory, October 5.

Dow Chemical Company. 1982. Daily Report for the Dow/DOE No. 1 Sweezy-Parcperdue Test Well. Submitted to F. Goldsberry, U.S. Department of Energy, Houston, by R. Storm, Site Manager.

Durrett, L. 1981. A Summary of the Testing Phase-Sweet Lake Prospect, June 19-November 30, 1981. Magma Gulf-Technadril, Inc., Cameron Parish, La.

Engineering Science, Inc. 1983. A Report on a Flare Efficiency Study. Prepared for the Chemical Manufacturers Association, Washington, D.C.

Goldsberry, F. 1980. "A Comparative Analysis of Geopressured Geothermal (GEO 2) Resource Environmental Effects." Trans. Am. Nuch Soc. 34, 127.

Goldsberry, F. 1983. Staff Member, U.S. Department of Energy, Houston. Personal communication with A. W. Reed, Oak Ridge National Laboratory, September 14.

Gustavson, T. 1979. Envirommental: Baseline Monitoring in the Area General Crude Oil-Department of Energy Pleasant Bayou Number 1. Appendix III: Noise Survey. University of Texas, Bureau of Economic Geology, Austin, Tex.

Gustavson, T. 1982. Environmental Baseline Monitoring in the Area of General Crude Oil-Department of Energy Pleasant Bayou Number 2-A Geopressured Geothermal Test Well-1980. University of Texas, Bureau of Economic Geology, Austin, Tex.

Gustavson, T. C., and C. W. Kreitler. 1976. "Geothermal Resources of the Texas Gulf Coast-Environmental Concerns Arising from the Production and Disposal of Geothermal Waters." University of Texas, Austin, Bureau Economic Geology Circular 76-7. 
Gustavson, T., and M. M. McGraw. 1978. "Potential Environmental Concerns Associated with the Development of Geopressured-Geothermal Resources of the United States Gulf Coast." Geothermal Resources Council, Transactions 2, 245.

Gustavson, T., R. C. Howard, and D. McGookey. 1980. Environmental Baseline Monitoring in the Area of General Crude Oil-Department of Energy Pleasant Bayou Number 2-A Geopressured-Geothermal Test Well-1979. Appendix I. Air Quality Monitoring. University of Texas, Bureau of Economic Geology, Austin, Tex.

Gustavson, T., R. C. Howard, and D. McGookey. 1982. Environmental Baseline Monitoring in the Area of General Crude Oil-Department of Energy Pleasant Bayou Number 2-A Geopressured-Geothermal Test Well-1980. University of Texas, Bureau of Economic Geology, Austin, Tex.

Keeley, D., and J. R. Meriwether. 1982. Third Progress Report on the Analytical Chemistry Performed on the Fluids from the Parcperdue Geopressured Energy Project. University of Southwest Louisiana, College of Sciences, Lafayette, La.

Keeley, D., and J. R. Meriwether, Jr. 1983. Letter report to R. Storm, Dow Project Manager, "Chemical Analysis of Fluids from the Dow Geopressure Well," February 19.

Klett, M. G., and J. B. Galeski. 1976. Flare Systems Study. EPA-600/2-76-079. U.S. Environmental Protection Agency, Research Triangle Park, N.C.

Liverman, James L. 1978. Acting Assistant Secretary for the Environment, U.S. Department of Energy. Memorandum to R. D. Thorne, Acting Assistant Secretary for Energy Technology, U.S. Department of Energy.

Lombard, D. 1982a. Geopressure Program Manager, U.S. Department of Energy. Personal communication with J. W. Webb, Oak Ridge National Laboratory, September 9.

Lombard, D. 1982b. Geopressure Program Manager, U.S. Department of Energy. Personal communication with D. B. Hunsaker, Jr., Oak Ridge National Laboratory, November 23.

Newchurch, E. J., V. R. Van Sickle, A. L. Bachman, C. F. Bryan, D. P. Harrison, P. A. Muller, and C. G. Smith, Jr. 1979. "A Comparison of Six Geopressured-Geothermal Prospect Areas in the Louisiana Gulf Coast Region on the Basis of Potential Environmental Impacts." Proceedings, Fourth United States Gulf Coast Geopressured-Geothermal Energy Conference: Research and Development, Volume 3. M. H. Dorfman and W. L. Fisher, eds. Center for Energy Studies, University of Texas, Austin, Tex.

Storm, R. 1983. Site Manager, Dow Parcperdue Geopressure Design Well. Personal communications with D. B. Hunsaker, Jr., Oak Ridge National Laboratory, April 8 and 25, and with A. W. Reed, Oak Ridge National Laboratory, June 9.

Trahan, D. 1983. Staff member, Louisiana Geological Survey, Baton Rouge. Personal communication with D. B. Hunsaker, Jr., Oak Ridge National Laboratory, April 29. 
U.S. Department of Energy (DOE). 1978. Environmental Assessment, Geothermal Energy, Geopressure Subprogram, GCO-DOE, Pleasant Bayou No. 1, Brazoria County, Texcas. DOE/EA-0013. March.

U.S. Department of Energy (DOE). 1979a. Status Report, March 2, 1979, DOE/Industry Geopressured-Geothermal Energy Development Program.

U.S. Department of Energy (DOE). 1979b. Status Report, June 8, 1979, DOE/Industry Geopressured-Geothermal Energy Development Program.

U.S. Department of Energy (DOE). 1980a. Draft Environmental Assessment, Dow Parcperdue Geopressure Project; Vermilion Parish, Louisiana U.S. Department of Energy, Washington, D.C. March.

U.S. Department of Energy (DOE). 1980b. Environmental Assessment, Geothermal Energy Geopressure Subprogram, DOE Sweet Lake No. 1, Cameron Parish;"Lonisiana. DOE/EA-0065. February.

U.S. Department of Energy (DOE). 1981. Environmental Assessment, Geothermal Energy Geopressure Subprogram, DOE Gladys McCall Well Site, Cameron Parish, Louisiana. DOE/EA-0134. January.

U.S. Department of Energy (DOE). 1983. Geopressure-Geothermal Activities, Monthly Report, Activity in July 1983. U.S. Department of Energy, Nevada Operations Office. August.

U.S. Environmental Protection Agency (EPA). 1974. Information on Environmental Noise Requisite to Protect Public Health and Welfare with an Adequate Margin of Safety. EPA-550/9-74-004. Office of Noise Abatement and Control; Washington, D.C.

U.S. Environmental Protection Agency (EPA). 1980. Ambient Monitoring Guidelines for Prevention of Significant Deterioration.(PSD). EPA-450/4-80-012. Office of Air Quality Planning and Standards, Research Triangle Park, N.C.

Van Sickle, V. 1982a. Staff member, Louisiana Geological Survey, Baton Rouge, Louisiana. Personal communication with D. B. Hunsaker, Jr., Oak Ridge National Laboratory, August 30.

Van Sickle, V. 1982b. Staff member, Louisiana Geological Survey, Baton Rouge. Letter to A. W. Reed, with comments on Draft Evaluation of Environmental Mitigation and Monitoring Commitments at Four Geopressure Design Wells, Oak Ridge National Laboratory, November 12.

Van Sickle, V. 1982c. Staff member, Louisiana Geological Survey, Baton Rouge, Louisiana. Personal communication with K. M. Oakes, Oak Ridge National Laboratory, July 1.

Van Sickle, V. 1983. Staff member, Louisiana Geological Survey, Baton Rouge, Louisiana. Personal communication with A. W. Reed, Oak Ridge National Laboratory, July 29.

Wrighton, F. M., D. Bebout, D. R. Carver, C. C. Groat, and A. E. Johnson. 1981. Technical Support for Geopressured-Geothermal Well Activities in Louisiana Final Report for the Period Sept. 27, 1978-December 31, 1980. U.S. Department of Energy, Division of Geothermal Energy, Washington, D.C. 


\section{APPENDIX A-SU'MMARY OF RESEARCH CONCERNING THE EFFECTS OF DRILLING MUD PITS ON GROUNDWATER QUALITY}

Under contract to the American Petroleum Institute (API), Dames and Moore* performed research on the movement of trace elements from drilling mud pits and water impoundments at oil and gas well sites. This appendix summarizes the findings of this study and discusses their relevance to geopressured-geothermal wells.

Dames and Moore studied a total of eight sites, including two mud pits (Katy, Texas, and Iberville Parish, Louisiana) in the Louisiana-Texas geopressured zone, and another mud pit located near Carthage, Texas, approximately $240 \mathrm{~km}(150 \mathrm{mi})$ northwest of the geopressured zone. The mud pits were constructed between 5 and 12 years ago (Table A.1). The mud systems used in the wells were similar to those used in geopressure design wells, i.e., water based, barite-weighted, chrome, and ferrochrome-lignosulfonate muds with barite as the major mud constituent by weight.

The API study examined whether mud pits are an important source of groundwater contaminants by comparing the concentrations of water quality constituents in downgradient wells with those in upgradient, or background, wells. In general, higher concentrations were observed in downgradient wells. Sodium and chloride were observed to be the most motile ions, while the probable migration rates for heavy metals appeared to be very slow. The concentrations of downgradient wells for most heavy metals at most sites were below those established in the primary and secondary Drinking Water Standards (40 Federal Register 11990-11998, March 14, 1975).

Data for the three Louisiana-Texas mud pits are summarized in Tables A.2 to A.4. Table A.2 gives the average concentrations for water quality constituents in all wells vs control wells. The concentrations of sodium and chloride ions show the most pronounced pattern; the consistently higher concentrations in downgradient wells suggest that these highly motile ions are leaching from the mud pits. Table A.3 indicates the percentage of concentrations which exceeded the drinking water standards. In many cases, there is very little difference between the frequency of such exceedance for control wells vs all wells, suggesting that higher concentrations are the result of background conditions or imprecision in sampling laboratory analysis. Table A.4 indicates the magnitude of exceedances of drinking water standards.

\footnotetext{
"Dames and Moore, Inc. 1982. Analysis of Hydrologic and Envirommental Effects of Drilling Mud Pits and Produced Water Impoundments. Prepared for the American Petroleum Institute, Dallas, Tex.
} 
Data in Tables A.2 to A.4 provide one fairly clear example of a trace element leaching into groundwater. The Iberville mud pit appears to have been the source of arsenic in downgradient wells. The mean arsenic concentration in the control well was $0.013 \mathrm{mg} / \mathrm{L}$, while the mean concentration in all wells was almost ten times as great, $0.11 \mathrm{mg} / \mathrm{L}$.

The data in Tables A.2 to A.4 suggest that the mud pits are not a source of major groundwater contamination by the trace elements of greatest concern to human health. It should be noted, however, that the mud pits that were studied are only 5 to 12 years old, and some uncertainty remains as to their future effects on groundwater. 
Table A.1. Characteriatics of drilling mud pits

\begin{tabular}{lcccc}
$\begin{array}{c}\text { Well } \\
\text { location }\end{array}$ & $\begin{array}{c}\text { Type of } \\
\text { well }\end{array}$ & $\begin{array}{c}\text { Well } \\
\text { depth } \\
{[\mathrm{m}(\mathrm{ft})]}\end{array}$ & $\begin{array}{c}\text { Mud } \\
\text { system }\end{array}$ & $\begin{array}{c}\text { Pit } \\
\text { constructed }\end{array}$ \\
\hline Katy, TX & Gas (sweet) & $\begin{array}{c}3,180 \\
(10,420)\end{array}$ & $\begin{array}{c}\text { Chromium- } \\
\text { lignosulfonate }\end{array}$ & 1970 \\
Iberville Parish, LA & Oil & $\begin{array}{c}3,780 \\
(12,400)\end{array}$ & $\begin{array}{c}\text { Chromium- } \\
\text { lignosulfonate }\end{array}$ & 1977 \\
Carthage, TX & Oil & $\begin{array}{c}2,140 \\
(7,015)\end{array}$ & $\begin{array}{c}\text { Ferrochrome- } \\
\text { lignosulfonate }\end{array}$ & 1977 \\
\hline
\end{tabular}

Source: Dames and Moore, Inc. 1982. Analysis of Hydrologic and Envirommental Effects of Drilling Mud Pits and Produced Water Impoundments. Prepared for the American Petroleum Institute, Dallas, Tex.

Table A.2. Mean concentration of parameters in groundwater samples at drilling mud pit sites evaluated

\begin{tabular}{|c|c|c|c|c|c|c|c|}
\hline \multirow[b]{3}{*}{ Parameter } & \multirow[b]{3}{*}{ DWS $^{a}$} & \multicolumn{6}{|c|}{ Site } \\
\hline & & \multicolumn{2}{|c|}{ Katy, TX } & \multicolumn{2}{|c|}{$\begin{array}{c}\text { Iberville Parish, } \\
\text { LA } \\
\end{array}$} & \multicolumn{2}{|c|}{ Carthage, TX } \\
\hline & & $\begin{array}{c}\text { All } \\
\text { wells }\end{array}$ & $\begin{array}{l}\text { Control } \\
\text { wells }\end{array}$ & $\begin{array}{c}\text { All } \\
\text { wells }\end{array}$ & $\begin{array}{c}\text { Control } \\
\text { wells }\end{array}$ & $\begin{array}{c}\text { All } \\
\text { wells }\end{array}$ & $\begin{array}{l}\text { Control } \\
\text { wells }\end{array}$ \\
\hline \multicolumn{8}{|l|}{ Heavy Metals } \\
\hline Arsenic (As) & 0.05 & 0.026 & 0.042 & 0.110 & 0.013 & 0.088 & 0.077 \\
\hline Barium (Ba) & 1.0 & 1.9 & 0.9 & 0.6 & 0.4 & 0.3 & $<0.08$ \\
\hline Cadmium (Cd) & 0.01 & 0.009 & 0.009 & 0.007 & 0.008 & 0.009 & $<0.01$ \\
\hline $\begin{array}{l}\text { Hexavalent } \\
\text { Chromium }\left(\mathrm{Cr}^{+6}\right)\end{array}$ & 0.05 & $<0.05$ & $<0.05$ & $<0.04$ & $<0.04$ & 0.04 & $<0.03$ \\
\hline Total Chromium (Cr) & None & $<0.05$ & $<0.03$ & $<0.05$ & $<0.05$ & 0.02 & $<0.02$ \\
\hline Lead (Pb) & 0.05 & 0.06 & 0.05 & 0.18 & 0.26 & 0.08 & $<0.1$ \\
\hline Mercury (Hg) & 0.002 & 0.0037 & 0.0036 & 0.007 & 0.0038 & 0.009 & 0.004 \\
\hline Zinc (Zn) & $5.0^{b}$ & 0.144 & 0.140 & 0.2 & 0.2 & 0.53 & 0.8 \\
\hline \multicolumn{8}{|l|}{ Others } \\
\hline Sodium (Na) & None & 664 & 459 & 138 & 87 & 321 & 16.4 \\
\hline Chloride $(\mathrm{Cl})$ & $250^{b}$ & 864 & 407 & 398 & 276 & 661 & 8.0 \\
\hline
\end{tabular}

${ }^{a}$ DWS = Drinking Water Standard.

'Secondary Drinking Water Standard.

Source: Dames and Moore, Inc. 1982. Analysis of Hydrologic and Envirommental Effects of Drilling Mud Pits and Produced Water Impoundments. Prepared for the American Petroleum Institute, Dallas, Tex. 
Table A.3. Frequency of exceedance ${ }^{a}$ of primary and eecondary drinking water standards for selected parameters measured in groundwater samples at drilling mud pit sites evaluated (40 FR 11990-11998)

\begin{tabular}{|c|c|c|c|c|c|c|}
\hline \multirow[b]{3}{*}{ Parameter } & \multicolumn{6}{|c|}{ Site } \\
\hline & \multicolumn{2}{|c|}{ Katy, TX } & \multicolumn{2}{|c|}{$\begin{array}{c}\text { Iberville Parish, } \\
\text { LA }\end{array}$} & \multicolumn{2}{|c|}{ Carthage, TX } \\
\hline & $\begin{array}{l}\text { All } \\
\text { wells }\end{array}$ & $\begin{array}{c}\text { Control } \\
\text { wells }\end{array}$ & $\begin{array}{c}\text { All } \\
\text { wells }\end{array}$ & $\begin{array}{c}\text { Control } \\
\text { wells }\end{array}$ & $\begin{array}{c}\text { All } \\
\text { wells }\end{array}$ & $\begin{array}{c}\text { Control } \\
\text { wells }\end{array}$ \\
\hline \multicolumn{7}{|l|}{ Primary Standards } \\
\hline Arsenic (As) & 14.4 & 14.2 & $\mathbf{4 7 . 2}$ & 5.6 & 37.5 & 40.0 \\
\hline Barium (Ba) & 80.2 & 66.7 & 18.1 & 5.6 & 0.0 & 0.0 \\
\hline Cadmium (Cd) & 25.9 & 23.3 & 9.8 & 5.6 & 22.5 & 0.0 \\
\hline $\begin{array}{l}\text { Hexavalent } \\
\text { Chromium }\left(\mathrm{Cr}^{+6}\right)\end{array}$ & 0.0 & 0.0 & 0.0 & 0.0 & 0.0 & 0.0 \\
\hline Lead $(\mathrm{Pb})$ & 34.0 & 29.5 & 55.6 & $66: 7$ & 45.0 & 50.0 \\
\hline Mercury (Hg) & 54.2 & 66.7 & 61.1 & 55.6 & 55.0 & 60.0 \\
\hline \multicolumn{7}{|l|}{ Secondary Standards } \\
\hline Zinc (Zn) & 0.0 & 0.0 & 0.0 & 0.0 & 2.5 & 10.0 \\
\hline Chloride $(\mathrm{Cl})$ & 75.0 & 75.0 & 78.1 & 75.1 & 75.0 & 0.0 \\
\hline
\end{tabular}

${ }^{a}$ Percent of samples found to exceed primary or secondary drinking water standards calculated as the number of samples in exceedance divided by the total number of samples for all wells or for background, or upgradient, wells.

Source: Dames and Moore, Inc. 1982. Analysis of Hydrologic and Environmental Effects of Drilling Mid Pits and Prodiced Water Impoundments. Prepared for the American Petroleum Institute, Dallas, Tex.

Table A.4. Magnitude ${ }^{a}$ of exceedance of primary and secondary drinking water standards for selected parameters measured in groundwater samples at drilling mud pit sites evaluated (40 FR 11990-11998)

\begin{tabular}{|c|c|c|c|c|c|c|}
\hline \multirow[b]{3}{*}{ Parameter } & \multicolumn{6}{|c|}{ Site } \\
\hline & \multicolumn{2}{|c|}{ Katy, TX } & \multicolumn{2}{|c|}{$\begin{array}{c}\text { Iberville Parish, } \\
\text { LA }\end{array}$} & \multicolumn{2}{|c|}{ Carthage, TX } \\
\hline & $\begin{array}{l}\text { All } \\
\text { wells }\end{array}$ & $\begin{array}{l}\text { Control } \\
\text { wells }\end{array}$ & $\begin{array}{c}\text { All } \\
\text { wells }\end{array}$ & $\begin{array}{c}\text { Control } \\
\text { wells }\end{array}$ & $\begin{array}{c}\text { All } \\
\text { wells }\end{array}$ & $\begin{array}{c}\text { Control } \\
\text { wells }\end{array}$ \\
\hline \multicolumn{7}{|l|}{ Primary Standards } \\
\hline Arsenic (As) & $3.2 \times$ & $5.0 x$ & $4.4 \times$ & $1.7 \times$ & $4.2 \times$ & $3.4 \times$ \\
\hline Barium (Ba) & $2.2 \times$ & $2.1 \times$ & $1.6 \times$ & $3.1 \times$ & None & None \\
\hline Cadmium (Cd) & $1.6 \times$ & $1.8 \times$ & $2.7 \times$ & $4.7 \times$ & $1.6 \times$ & None \\
\hline $\begin{array}{l}\text { Hexavalent } \\
\text { Chromium }\left(\mathrm{Cr}^{+6}\right)\end{array}$ & None & None & None & None & None & None \\
\hline Lead $(\mathrm{Pb})$ & $1.8 \times$ & $2.1 \times$ & $5.6 \times$ & $7.4 \times$ & $2.0 \times$ & $2.0 \times$ \\
\hline Mercury (Hg) & $3.2 \times$ & $2.7 \times$ & $4.3 \times$ & $2.4 \times$ & $8.1 \times$ & $3.0 \times$ \\
\hline Secondary Standards & & & & & & \\
\hline $\begin{array}{l}\text { Zinc }(\mathrm{Zn}) \\
\text { Chloride }(\mathrm{Cl})\end{array}$ & $\begin{array}{l}\text { None } \\
4.5 \times\end{array}$ & $\begin{array}{l}\text { None } \\
3.2 \times\end{array}$ & $\begin{array}{l}\text { None } \\
1.9 \times\end{array}$ & $\begin{array}{l}\text { None } \\
1.4 \times\end{array}$ & $\begin{array}{l}1.4 \times \\
3.5 \times\end{array}$ & $\begin{array}{l}1.4 \times \\
\text { None }\end{array}$ \\
\hline
\end{tabular}

a Average magnitude of exceedance of drinking water standards in wells for each site calculated as the mean concentration of each exceeding parameter divided by the DWS limit.

Source: Dames and Moore, Inc. 1982. Analysis of Hydrologic and Envirommental Effects of Drilling Mud Pits and Produced Water Impoundments. Prepared for the American Petroleum Institute, Dallas, Tex. 


\section{INTERNAL DISTRIBUTION}

\author{
1. L. W. Barnthouse \\ 2. W. J. Boegly, Jr. \\ 3-4. C. R. Boston \\ 5. R. S. Carlsmith \\ 6. G. K. Eddlemon \\ 7. W. Fulkerson \\ 8. C. C. Gilmore \\ 9. S. G. Hildebrand \\ 10. N. E. Hinkle \\ 11. D. B. Hunsaker, Jr. \\ 12. S. V. Kaye \\ 13. C. R. Kerley \\ 14. R. M. Lee \\ 15. J. F. McBrayer \\ 16. L. N. McCold
}

17. C. H. Petrich

18-19. A. W. Reed

20. J. H. Reed

21-22. R. D. Roop

23. M. Schweitzer

24. R. I. Van Hook

25. J. W. Webb

26. T. J. Wilbanks

27. D. J. Wilkes

28. H. E. Zittel

29. ORNL Patent Office

30-31. Central Research Library

32. Document Reference Section

33-34. Laboratory Records

35. Laboratory Records (RC)

\section{EXTERNAL DISTRIBUTION}

36. Office of Assistant Manager for Energy Research and Development, DOE-ORO, Oak Ridge, TN 37830

37. Mr. Ronald F. Bendersky, University of Michigan, Graduate School of Business Administration, 291 Assembly Hall, Ann Arbor, MI 48109.

38. Mr. Richard Benson, Director; Office of Renewable Technologies, U.S. Department of Energy, CE-32, Rm. 5G 086, 1000 Independence Avenue, S.W., Washington, DC 20585.

39. Mr. James C. Bresee, U.S. Department of Energy, Geothermal and Hydropower Technologies Division, CE-324, Rm. 5G 070, 1000 Independence Avenue, S.W., Washington, DC 20585.

40. Dr. Joseph F. Calabro, Pennsylvania Gas and Water Company, Water Quality Department, 135 Jefferson Avenue, Scranton, PA 18503.

41. Mr. James C. Cotter, U.S. Department of Energy, Nevada Operations Office, P.O. Box 14100, Las Vegas, NV 89114.

42. Mr. Steven G. DeCicco, U.S. Synthetic Fuels Corporation, 2121 K Street, NW, Washington, DC 20586.

43. Dr. Myron Dorfman, Department of Petroleum Engineering, University of Texas, Austin, TX 78712.

44. Dr. Fred Goldsberry, U.S. Department of Energy, Geopressure Project Office, 3 Northport Drive, Houston, TX 77060. 
45. Dr. Charles P. Groat, Louisiana Geological Survey, Louisiana State University, Highland Road, Baton Rouge, LA 70803.

46. Dr. Thomas Gustavson, Bureau of Economic Geology, University of Texas, Austin, TX 78712.

47. Ms. Elizabeth Jankas, U.S. Department of Energy, Office of Environmental Compliance, EP-361, Rm. 4G 057, 1000 Independence Avenue, S.W., Washington, DC 20585.

48. Dr. Gary Kinsland, University of Southwest Louisiana, 100 East University Avenue, Lafayette, LA 70504.

49. Dr. Todd R. LaPorte, Professor, Political Science, Institute of Government Studies, University of California, 109 Moses Hall, Berkeley, CA 94720.

50. Mr. David B. Lombard, U.S. Department of Energy, Geothermal and Hydropower Technologies Division; CE-324, Rm. 5G 046, 1000 Independence Avenue, S.W., Washington, DC 20585.

51. Dr. John Meriwether, University of Southwest Louisiana, 100 East University Avenue, Lafayette, LA 70504 .

52. Dr. Robert Morton, Bureau of Economic Geology, University of Texas, Austin, TX 78712.

53. Mr. Laurence I. Moss, Energy/Environmental Design and Policy Analysis, 5769 Longs Peak Route, Estes Park, CO 80517.

54. Dr. Robert E. Ogren, Biology Department, Wilkes College, Wilkes-Barre, PA 18701.

55. Mr. Ray Pelletier, U.S. Department of Energy, Office of Environmental Compliance, EP-362, Rm. 4G 047, 1000 Independence Avenue, S.W., Washington, DC 20585.

56. Mr. Paul R. Pike, Environmental Division, St. Louis Electric Company, 1901 Gratiot, St. Louis, MO 63166.

57. Mr. Ronald Stearns, U.S. Department of Energy, Nevada Operations Office, P.O. Box 14100, Las Vegas, NV 89114.

58. Ms. Virginia Van Sickle, Louisiana Geological Survey, Louisiana State University, Highland Road, Baton Rouge, LA 70803.

59. Dr. William H. Williams, Division Manager, American Bell, Building 83, Room 1B23, 100 Southgate Parkway, Morristown, NJ 07960.

60-86. Technical Information Center, U.S. Department of Energy, P.0. Box 62, Oak Ridge, TN 37830. 